\title{
Evaluation of sexual dysfunction and female sexual dysfunction indicators in women with type 2 diabetes: a systematic review and meta-analysis
}

\author{
Elham Rahmanian, Nader Salari", Masoud Mohammadi and Rostam Jalali
}

\begin{abstract}
Type 2 diabetes is one of the most common chronic diseases worldwide, and one of the long-term complications of this disease is sexual dysfunction in women with type 2 diabetes, which has been studied in fewer studies. The aim of this study is to determine the overall prevalence of sexual dysfunction in women with type 2 diabetes and its indicators with systematic and meta-analysis approach. The present meta-analysis study reviewed articles published foreign journals by searching the MEDLINE, Cochrane Library, Science direct, Embase, Proquest and Persian databases, including Iranmedex, Magiran, and SID between January 2000 to December 2018. The heterogeneity of studies was studied using the $\mathrm{I}^{2}$ index and data analysis was carried out in Comprehensive Meta-Analysis software. The Meta-analysis review of 25 studies and 3892 individuals aged 70-18 years showed that the overall prevalence of sexual dysfunction in women with type 2 diabetes was $68.6 \%$ (95\% Cl 61.1-75.3\%). The highest and lowest prevalence of sexual dysfunction was 94.4\% in Iranian women with type 2 diabetes (95\% Cl 91.9\%-96.3\%) in 2014 and 17\% in Italian women with diabetes Type 2 (95\% Cl 6.4-36.9\%) in 2015. Results of meta-regression showed that with the increase in sample size and year of study, the overall prevalence of sexual dysfunction decreased and increased, respectively and the differences were statistically significant $(P<0.05)$. Regarding the high prevalence of sexual dysfunction in women with type 2 diabetes, health policymakers need to take appropriate measures to address this disorder in patients with type 2 diabetes.
\end{abstract}

Keywords: Prevalence, Disorder, Type 2 diabetes, Sexual function, Meta-analysis

\section{Background}

Diabetes mellitus is characterized by hyperglycemia and carbohydrate metabolism, fat, and protein deficiency. It is one of the most common and costly chronic diseases in the world, and affects about $2-5 \%$ of adults in industrial societies [1]. Given the increasing number of diabetes in the world, the World Health Organization (WHO) has described it as a hidden epidemic, with a global prevalence of $6.4 \%$ (285 million people) among 20-79 age group in 2010. However, this figure is projected to increase to $7.7 \%$ in 2030 (439 million per year),

*Correspondence: nader.salari.1344@gmail.com

Department of Nursing, School of Nursing and Midwifery, Kermanshah University of Medical Sciences, Kermanshah, Iran and to more than 600 million per year in 2035 [2]. There are now more than 380 million people with diabetes worldwide, and this figure is estimated to be 29.1 million people in the United States, that is $9.3 \%$ of the total population [3]. The statistics provided by the International Federation of Diabetes show that approximately 5 million people aged 20-79 years are suffering from diabetes in Iran, with a prevalence of 8.5\% [4]. Diabetes is known as one of the most important risk factors for cardiovascular disease, with diabetic patients being at risk of cardiovascular disease 2 to 4 times higher than the general population [2-4]. Diabetes can manifest as microvascular or macrovascular complications. The most important microvascular complications include nephropathy, retinopathy, neuropathy and the most important 
macrovascular complications include hypertension and coronary artery disease [1-4]. This chronic disease is also able to cause severe ocular, renal, and neuropathic complications in patients to blindness, renal, cardiovascular disease, amputation, and disability [5-7]. Such chronic and debilitating conditions have widespread effect on the ability of the individual and the daily activities of these patients, which in turn affects the quality of life in these patients [8].

One of the long-term complications of diabetes is sexual dysfunction. Previous studies have shown the negative effects of this disease on the sexual function and health of people with diabetes in both genders [9-11]. Sexual health is defined by WHO as a physical, emotional, psychological, and social well-being in terms of sexual desire, not just lack of disease, dysfunction, or disability [12], regardless of the range of sexual desires that are the basis of important behaviors and lead to sexual health. Sexual health is the result of interaction of cardiovascular, neurological, and hormonal factors and is influenced by individual factors, interpersonal relationships, traditions governing family and community, culture, and religion [13, 14]. Sexual dysfunction is a heterogeneous combination of disorders that is characterized as a major disorder in one's ability to respond to sexual response or sexual pleasure. These disorders include abnormalities in women's orgasm, arousal, pain, and unknown sexual dysfunction [15]. Although various studies have reported high prevalence of sexual dysfunction in women with diabetes compared with non-diabetic women [16-31], the sexual problems of diabetic women and its related risk factors are not well defined and highlighted. There are also fewer studies on diabetic women than diabetic men [32-37]. In a study conducted in Iran, the prevalence of sexual dysfunction was reported to be $88 \%$ in women with type 2 diabetes [22], which can significantly affect their interest, satisfaction, and ability to participate in sexual activity. Such conditions can be due to vascular, neurological, and psychological problems caused by diabetes or the result of negative effects of the drugs used in these patients [32-38]. On the one hand, the sexual health of diabetic patients, as a component of care, has often been neglected, perhaps because it has been considered by many individuals as a taboo and has thus been neglected [39]. On the other hand, previous studies provide non-transparent and different information and various studies show in consistent scores for sexual dysfunction indices in women with type 2 diabetes. Thus, the aim of this systematic review and meta-analysis is to answer the questions, what is the level of overall prevalence of sexual dysfunction in women with type 2 diabetes and the overall score of female sexual function index in women with diabetes?

\section{Methods}

\section{Search strategy}

This study is a systematic review and meta-analysis and is the result of findings of previous relevant researches. First, articles published in domestic and foreign journals were retrieved by searching MEDLINE, Cochrane Library, Sciencedirect, Embase, Proquest databases and Persian databases, including Iranmedex, Magiran, and SID were restored during January 2000 to December 2018. The researcher carried out the searching process by using the keywords of Diabetes, Non-insulin dependent diabetes, Type 2 diabetes, Sexual dysfunction, and Women in Persian sources, and Diabetes, Non-insulin-dependent diabetes, Sexual dysfunction, women in English databases, as well as both Persian and English words in the Google scholar search engine. It should be noted that (AND) and (OR) operators were combined in order to provide more comprehensive access to all articles; therefore the OR operators was used to check the common names for a disorder like (Blood glucose OR Hyperglycemia), (Diabetes OR Non-insulin dependent diabetes), (Sexual Behavior OR Sexual Orientation), (Disorders OR Dysfunction). AND operator was also used between the keywords (Diabetes AND Non-InsulinDependent Diabetes AND Sexual Dysfunction) through the matching words in the MeSH browser.

\section{Criteria for selection and evaluation of articles}

First, all the articles were collected using the selected keywords and when the search was completed, a list of abstracts was prepared and after hiding the articles' profile, including the name of the journal and the author, the full text of the articles was provided to the reviewers. Each article is read independently by two reviewers. If the article is rejected, the reason was mentioned. If there is a difference between two reviewers, the article was judged by the third reviewer and the third referee's opinion was taken into account. Inclusion criteria included Persian and English articles based on crosssectional, case-control, and cohort studies to obtain the prevalence of sexual dysfunction in women with type 2 diabetes as well as to investigate the relationship between clinical and metabolic factors with sexual dysfunction in women with type 2 diabetes. Review, interventional articles, as well as articles with no access to their full text or poor rating quality, were excluded from the list of final articles. Moreover, studies that reported female sexual function indices (FSFI), including desire, arousal, lubrication, orgasm, satisfaction, and pain in women with type 2 diabetes were also separated from the final studies so that they will be used in the meta-analysis phase while investigating mean score and overall standard deviation of these indices. In order to investigate gray literature, 
that part of the evidence and documentation that has not been published for any reason, a comprehensive review on Google has been put on the agenda in the present study. To review the articles collected, a checklist of articles' profile, included the researcher's name, the article's title, the year and place of the study, the sample size, the prevalence of the disorder in studies based on the PRISMA chart, included a four-step process consisting of initial search and identification of the studies based on keywords, screening of articles based on duplicate searches and similar articles, the criteria for accepting articles based on inclusion and exclusion criteria, and finally the articles selected for entering meta-analysis, was prepared. Duplicate and multiple publications from the same population will be removed using citation management, software EndNote (version X7, for Windows, Thomson Reuters).

\section{Quality assessment}

STROBE checklist was used to investigate the studies. This checklist consists of 22 sections, 18 of which are general and are used for all observational studies, including cohort, case-control, and cross-sectional. There are also 4 specific sections that depend on the type of study, and various methodological aspects that include objectives of the study, determining the appropriate sample size, type of study, sampling method, research population, data collection method, variables definition, and method, data collection tools, objectives under study, statistical test, and findings of the study. Accordingly, the maximum score is considered as 32 , and articles with a score $>14$ were considered to be low in terms of quality assessment and excluded from the study.

\section{Statistical analysis}

Heterogeneity was investigated using the $\mathrm{I}^{2}$ test. Generally, heterogeneity is classified into three categories, heterogeneity $>25 \%$ (low heterogeneity), $25-75 \%$ (average heterogeneity), and $75 \%>$ higher (high heterogeneity). Data analysis was carried out using Comprehensive Meta-analysis software (Biostat, Englewood, NJ, USA version 3 ) and probability bias of the results was calculated by using funnel plot and Egger test $(\mathrm{P}<0.05)$, Begg and Mazumdar $(\mathrm{P}<0.1)$. Moreover, meta-regression test in two dimensions of sample size and years of research was used to investigate the effects of the potentially effective factors on the heterogeneity of the studies.

\section{Results}

\section{Search output}

Based on studies on the prevalence of sexual dysfunction in women with type 2 diabetes, including articles published in domestic and foreign journals, and searching
Iranmedex, Magiran, and SID databases ( $\mathrm{n}=89$ articles), Medline (PubMed) $(\mathrm{n}=112$ articles), and Sciencedirect $(\mathrm{n}=583$ articles), Proquest $(\mathrm{n}=63$ articles), Embase, ( $\mathrm{n}=52$ articles), Cochrane Library ( $\mathrm{n}=12$ articles), and Google Scholar search engines( $\mathrm{n}=366$ articles), and a total of 1273 articles were obtained. Then, a total of 955 duplicate articles were excluded and 318 articles met the inclusion criteria based on preliminary studies. Finally, 25 articles were entered the meta-analysis phase after eliminating 285 unrelated articles and 8 articles with no access to their abstracts and original articles as well as their low quality during the secondary investigation (Fig. 1). Profiles of these articles were reported in Table 1 [31, 34, 40-62].

\section{Heterogeneity and publication bias}

The heterogeneity of the studies was evaluated using the $\mathrm{I}^{2}$ test and its value was obtained $\mathrm{I}^{2}=94.5 \%$ indicating a high heterogeneity in the studies included. Therefore, the random effects model was used to combine the results of the studies. The results of the publication bias were measured using Egger test (Fig. 2), which was not statistically significant $(P=0.103)$, Begg and Manzumdar test also showed no significant publication bias in the present study $(\mathrm{P}=0.833)$.

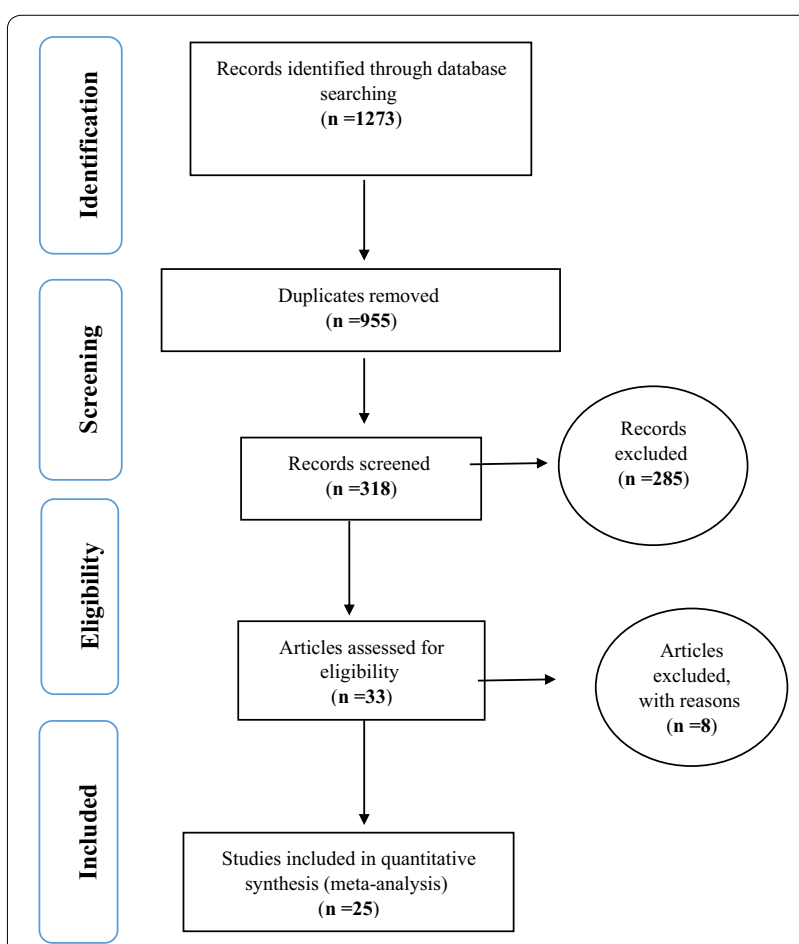

Fig. 1 The flowchart on the stages of including the studies in the systematic review and meta-analysis (PRISMA 2009) 
Table 1 Specifications of studies entered the study

\begin{tabular}{|c|c|c|c|c|c|c|c|}
\hline Row & Author [references] & Publication year & Area & Participants' age & Sample size & Prevalence & Quality assessment \\
\hline 1 & Erol et al. [40] & 2003 & Turkey & $38.8 \pm 1.1$ & 72 & 51.3 & Moderate \\
\hline 2 & Doruk et al. [41] & 2005 & Turkey & $41 \pm 1.1$ & 50 & 42 & Moderate \\
\hline 3 & Najafi et al. [42] & 2006 & Iran & $48.1 \pm 9.5$ & 26 & 76 & Moderate \\
\hline 4 & Mezones et al. [43] & 2008 & Peru & $53.3 \pm 4.1$ & 36 & 75 & Moderate \\
\hline 5 & Ogbera et al. [44] & 2009 & Nigeria & $50.5 \pm 1.2$ & 58 & 87.9 & Moderate \\
\hline 6 & Esposito et al. [45] & 2010 & Italy & $57.9 \pm 6.9$ & 595 & 53.4 & Moderate \\
\hline 7 & Ziaeirad et al. [46] & 2010 & Iran & $46.3 \pm 5.2$ & 91 & 86.8 & High \\
\hline 8 & Yencilk et al. [34] & 2010 & Turkey & $39.2 \pm 9.4$ & 62 & 80.6 & Moderate \\
\hline 9 & Giugliano et al. [47] & 2010 & Italy & $35-70$ & 659 & 53.1 & Moderate \\
\hline 10 & Nowosielski et al. [48] & 2011 & Poland & $47.6 \pm 7.02$ & 133 & 27.06 & Moderate \\
\hline 11 & Shi et al. [49] & 2012 & China & $47.3 \pm 7.1$ & 106 & 79.2 & High \\
\hline 12 & Sharifiaghdas et al. [50] & 2012 & Iran & $42.1 \pm 5.9$ & 45 & 71 & Moderate \\
\hline 13 & Cortelazzi et al. [31] & 2013 & Italy & $18-50$ & 34 & 67.6 & Moderate \\
\hline 14 & Erten et al. [51] & 2013 & Turkey & $51.3 \pm 5.8$ & 38 & 47.4 & Moderate \\
\hline 15 & Vafaeimanesh et al. [52] & 2014 & Iran & $48.2 \pm 6.6$ & 110 & 53.6 & Moderate \\
\hline 16 & Cordero et al. [53] & 2014 & Mexico & $40-70$ & 120 & 81.6 & Moderate \\
\hline 17 & Shadman et al. [54] & 2014 & Iran & $54.4 \pm 9.8$ & 420 & 94.4 & Moderate \\
\hline 18 & Bjerggaard te al [55] & 2015 & Denmark & $65 \pm 7$ & 348 & 68.3 & High \\
\hline 19 & Elyasi et al. [56] & 2015 & Iran & $42 \pm 10.1$ & 150 & 78.7 & Moderate \\
\hline 20 & Mazzilli et al. [57] & 2015 & Italy & $36.6 \pm 5.2$ & 24 & 17 & Moderate \\
\hline 21 & Ammar et al. [58] & 2016 & Tunisia & $40.8 \pm 4.8$ & 30 & 50 & Moderate \\
\hline 22 & Li et al. [59] & 2016 & China & $51 \pm 9$ & 184 & 75 & Moderate \\
\hline 23 & Bak et al. [60] & 2017 & Poland & $51.1 \pm 9.7$ & 114 & 68 & Moderate \\
\hline 24 & Turki et al. [61] & 2017 & Saudi Arabia & $40-50$ & 275 & 88.7 & Moderate \\
\hline 25 & Marques et al. [62] & 2018 & Portugal & $45-70$ & 112 & 70.9 & Moderate \\
\hline
\end{tabular}

\section{Funnel Plot of Standard Error by Logit event rate}

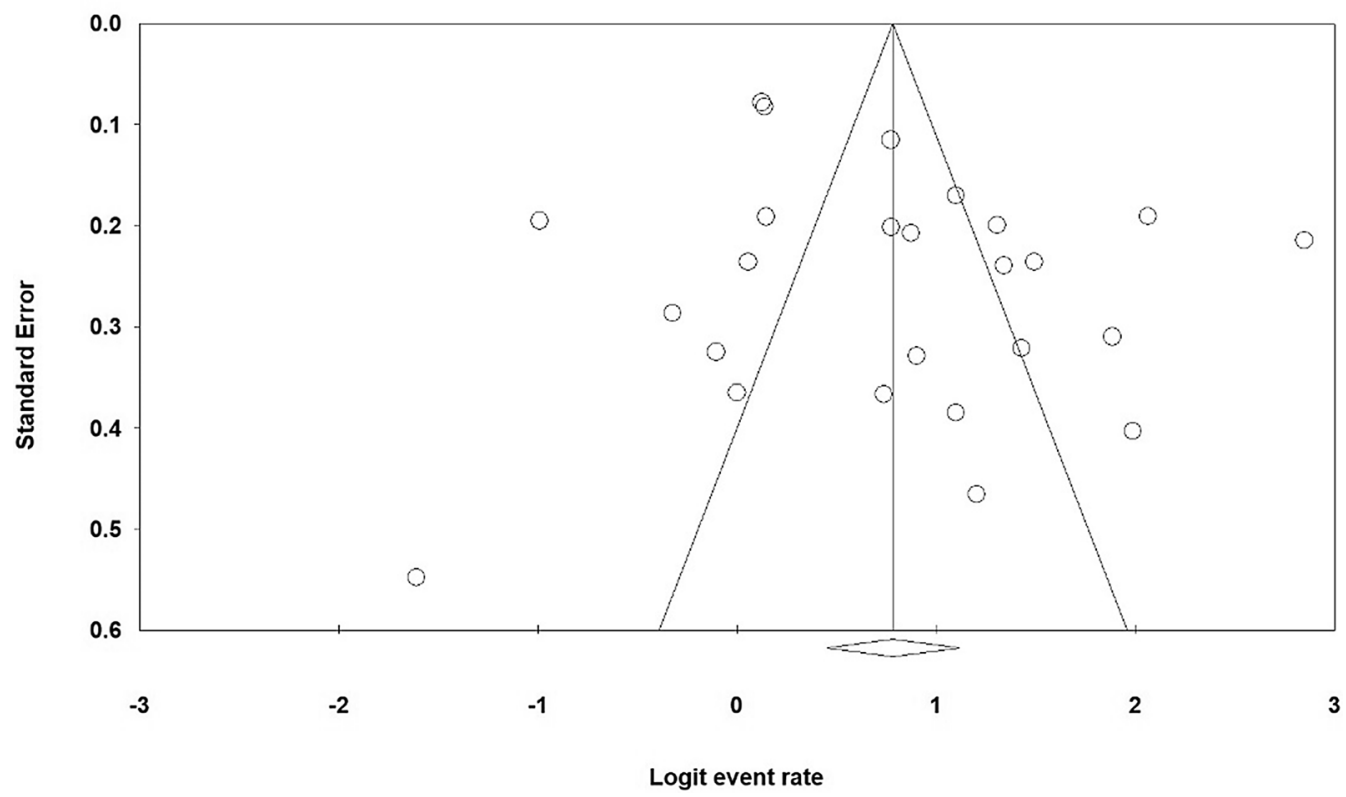

Fig. 2 Results of funnel plot on the prevalence of sexual dysfunction in women with type 2 diabetes 
The total sample size was 3892 with the age range of $18-70$ years. The overall prevalence of sexual dysfunction in women with type 2 diabetes was $68.6 \%$ based on the meta-analysis (95\% CI 61.1-75.3\%). The highest prevalence of sexual dysfunction was $94.4 \%$ among Iranian women with type 2 diabetes (95\% CI 91.9\%-96.3\%) in 2014 [58] and the lowest prevalence was observed among Italian women with type 2 diabetes $17 \%$ (95\% CI 6.4$36.9 \%$ ) in 2015 [53] (Fig. 3). In this figure, the prevalence of sexual dysfunction is shown based on the random effects model where the black square indicates the prevalence rate and the length of the line segment on which is located shows the $95 \%$ CI interval in each study, the diamond sign also shows the prevalence rate in all studies.

\section{Sensitivity analysis}

A sensitivity analysis was performed to ensure the stability results, after removing each study results did not change (Fig. 4).

\section{Study name}

\begin{tabular}{|c|c|c|c|c|c|}
\hline & $\begin{array}{c}\text { Event } \\
\text { rate }\end{array}$ & $\begin{array}{l}\text { Lower } \\
\text { limit }\end{array}$ & $\begin{array}{c}\text { Upper } \\
\text { limit }\end{array}$ & Z-Value & $p \cdot V$ \\
\hline hi.2012 & 0.792 & 0.705 & 0.859 & 5.594 & \\
\hline jerggaard.2015 & 0.684 & 0.633 & 0.731 & 6.694 & \\
\hline lowosielski.2011 & 0.271 & 0.202 & 0.352 & -5.079 & \\
\hline rol. 2003 & 0.514 & 0.400 & 0.627 & 0.236 & \\
\hline oruk.2005 & 0.420 & 0.292 & 0.559 & -1.126 & \\
\hline gbera.2009 & 0.879 & 0.768 & 0.941 & 4.927 & \\
\hline sposito.2010 & 0.534 & 0.494 & 0.574 & 1.680 & \\
\hline iaeirad.2010 & 0.868 & 0.782 & 0.924 & 6.083 & \\
\hline Yencilk.2010 & 0.806 & 0.689 & 0.887 & 4.440 & \\
\hline 1arques.2018 & 0.705 & 0.615 & 0.782 & 4.212 & \\
\hline Mezones.2008 & 0.750 & 0.585 & 0.864 & 54 & \\
\hline Elyasi.2015 & 0.787 & 0.714 & 0.845 & 6. & \\
\hline harifiaghdas.2012 & 0.711 & 0.564 & 0.824 & 2.739 & \\
\hline mmar.2016 & 0.500 & 0.328 & 0.672 & 0.000 & \\
\hline Cortelazzi.2013 & 0.676 & 0.505 & 0.811 & 12 & \\
\hline Mazzilli.2015 & 0.167 & 0.064 & 0.369 & -2.938 & \\
\hline Vafaeimanesh. & 0.536 & 0.443 & 0.627 & 0.762 & \\
\hline Cordero.2014 & 0.817 & 0.737 & 0.876 & 6.332 & \\
\hline Najafi.2006 & 0.769 & 0.572 & 0.892 & 2.587 & \\
\hline Bak.2017 & 0.684 & 0.593 & 0.763 & 3.837 & \\
\hline Shadman.2014 & 0.945 & 0.919 & 0.963 & 13.281 & \\
\hline Erten.2013 & 0.474 & 0.323 & 0.630 & -0.324 & \\
\hline Li.2016 & 0.750 & 0.682 & 0.807 & 6.453 & \\
\hline Turkan.2017 & 0.887 & 0.844 & 0.920 & 10.820 & \\
\hline \multirow[t]{2}{*}{ Giugliano.2010 } & 0.531 & 0.493 & 0.569 & 1.596 & 0.1 \\
\hline & 0.686 & 0.611 & 0.753 & 4.648 & \\
\hline
\end{tabular}

\section{Event rate and $95 \% \mathrm{CI}$}

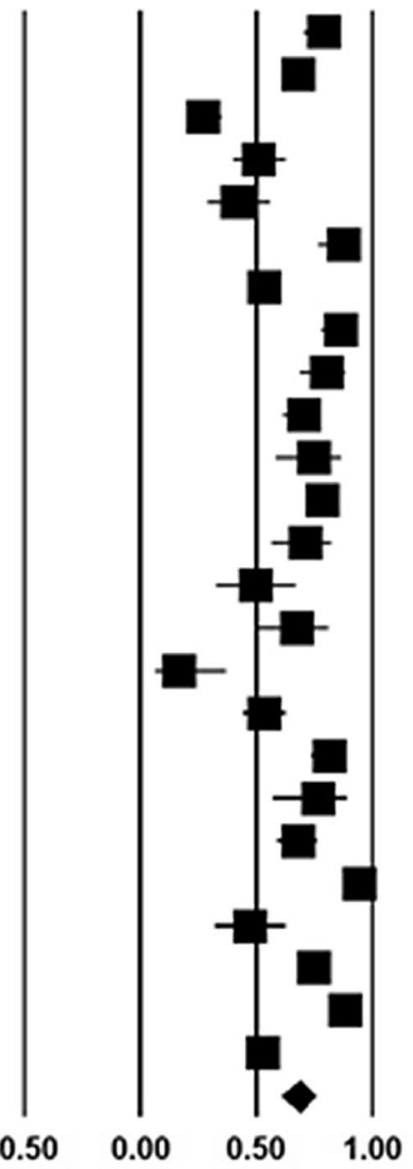

Favours A Favours B

\section{Meta Analysis}

Fig. 3 Overall prevalence of sexual dysfunction in women with type 2 diabetes based on the random model 


\begin{tabular}{|c|c|c|c|c|c|}
\hline \multirow[t]{2}{*}{ Study name } & \multicolumn{5}{|c|}{ Statistics with study removed } \\
\hline & Point & $\begin{array}{l}\text { Lower } \\
\text { limit }\end{array}$ & $\begin{array}{l}\text { Upper } \\
\text { limit }\end{array}$ & Z-Value & p-Value \\
\hline Shi.2012 & 0.681 & 0.604 & 0.750 & 4.400 & 0.000 \\
\hline Bjerggaard.2015 & 0.686 & 0.605 & 0.758 & 4.308 & 0.000 \\
\hline owosielski.2011 & 0.703 & 0.633 & 0.765 & 5.304 & 0.000 \\
\hline Erol.2003 & 0.693 & 0.616 & 0.760 & 4.687 & 0.000 \\
\hline oruk.2005 & 0.696 & 0.621 & 0.763 & 4.822 & 0.000 \\
\hline Ogbera.2009 & 0.677 & 0.600 & 0.745 & 4.340 & 0.000 \\
\hline Esposito. 2010 & 0.693 & 0.611 & 0.764 & 4.418 & 0.000 \\
\hline Ziaeirad.2010 & 0.677 & 0.600 & 0.745 & 4.346 & 0.000 \\
\hline Yencilk.2010 & 0.681 & 0.604 & 0.749 & 4.404 & 0.000 \\
\hline Marques.2018 & 0.686 & 0.607 & 0. & 4.451 & 0.000 \\
\hline Mezones.2008 & 0.684 & 0.607 & 0.752 & 4.474 & 0.000 \\
\hline Elyasi.2015 & 0.681 & 0.604 & 0.750 & 4.394 & 0.000 \\
\hline Sharifiaghdas.20 & 0.685 & 0.608 & 0.754 & 4.498 & 0.000 \\
\hline Ammar.2016 & 0.693 & 0.617 & 0.760 & 4.716 & 0.000 \\
\hline Cortelazzi.2013 & 0.687 & 0.610 & 0.755 & 4.540 & 0.000 \\
\hline Mazzilli.2015 & 0.702 & 0.629 & 0.767 & 5.084 & 0.000 \\
\hline Vafaeimanesh.2 & 40.692 & 0.615 & 0.760 & 4.634 & 0.000 \\
\hline Cordero.2014 & 0.680 & 0.603 & 0.748 & 4.385 & 0.000 \\
\hline Najafi.2006 & 0.683 & 0.606 & 0.751 & 4.472 & 0.000 \\
\hline Bak.2017 & 0.686 & 0.608 & 0.755 & 4.465 & 0.000 \\
\hline Shadman.2014 & 0.667 & 0.598 & 0.729 & 4.584 & 0.000 \\
\hline Erten.2013 & 0.694 & 0.618 & 0.761 & 4.747 & 0.000 \\
\hline Li.2016 & 0.683 & 0.605 & 0.753 & 4.392 & 0.000 \\
\hline Turkan.2017 & 0.674 & 0.600 & 0.740 & 4.450 & 0.000 \\
\hline Giugliano.2010 & 0.693 & 0.611 & 0.764 & 4.424 & 0.000 \\
\hline & 0.686 & 0.611 & 0.753 & 4.648 & 0.000 \\
\hline
\end{tabular}

\section{Event rate $(95 \% \mathrm{Cl})$ with study removed}

$\mid$
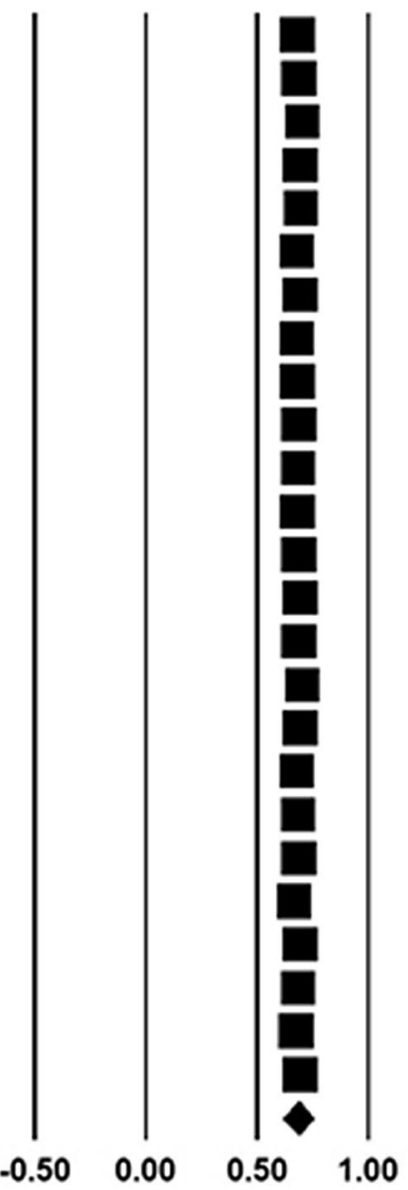

Favours A

Favours B

\section{Meta Analysis}

Fig. 4 Results of sensitivity analysis

\section{Meta-regression analysis}

In order to investigate the effects of potentially effective factors on the heterogeneity of the prevalence of sexual dysfunction in women with type 2 diabetes, meta-regression test was applied to two factors of sample size and year of study (Fig. 5). With an increase in the sample size, the overall prevalence of sexual dysfunction is reduced in women with Type 2 diabetes, which is statistically significant (Fig. 4) $(\mathrm{P}<0.05)$. It is also reported in this figure that with an increase in the year of the research, the overall prevalence of sexual dysfunction in women with type 2 diabetes is increased, which was also statistically significant $(\mathrm{P}<0.05)$.

Scores of female sexual function index

In this study, information on FSFI score including desire, arousal, lubrication, orgasm, satisfaction, and pain were also extracted from the studies reviewed. The mean score in women of the case group (type II diabetes) was lower than that of the control group in all studies that examined 


\section{Regression of Sample on Logit event rate}

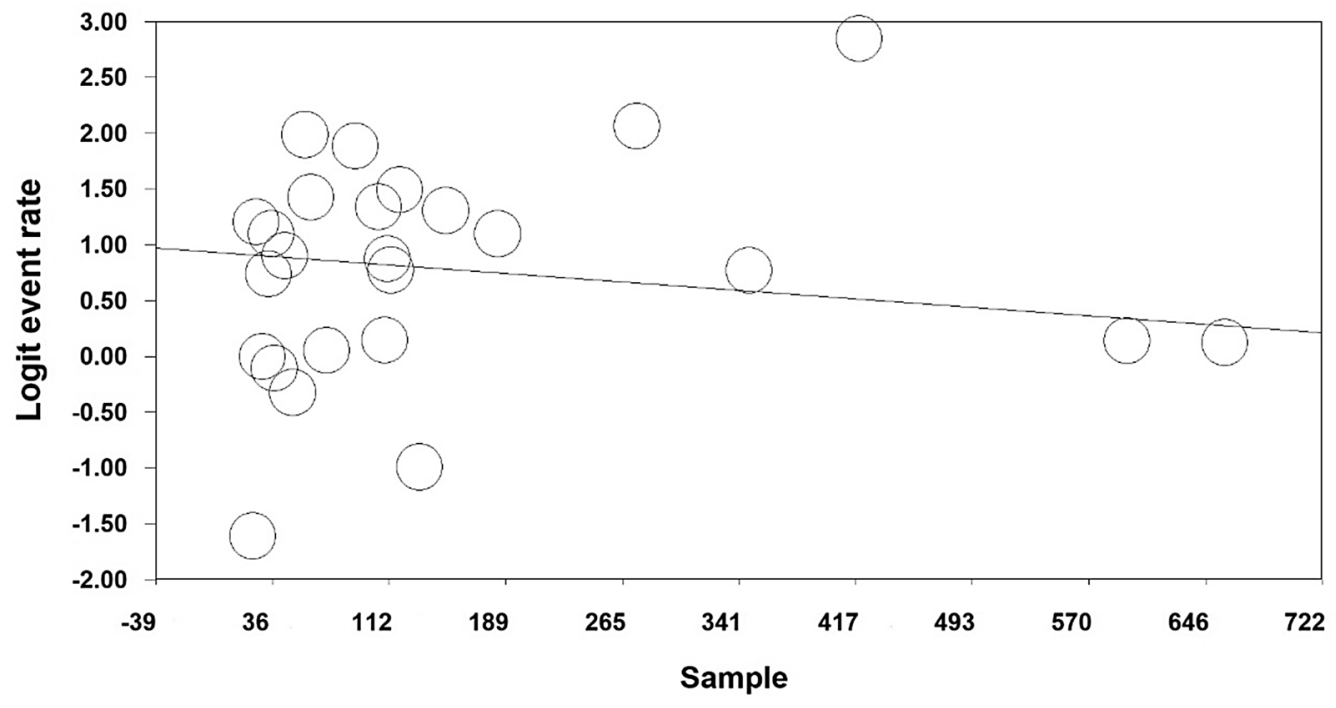

Regression of Years on Logit event rate

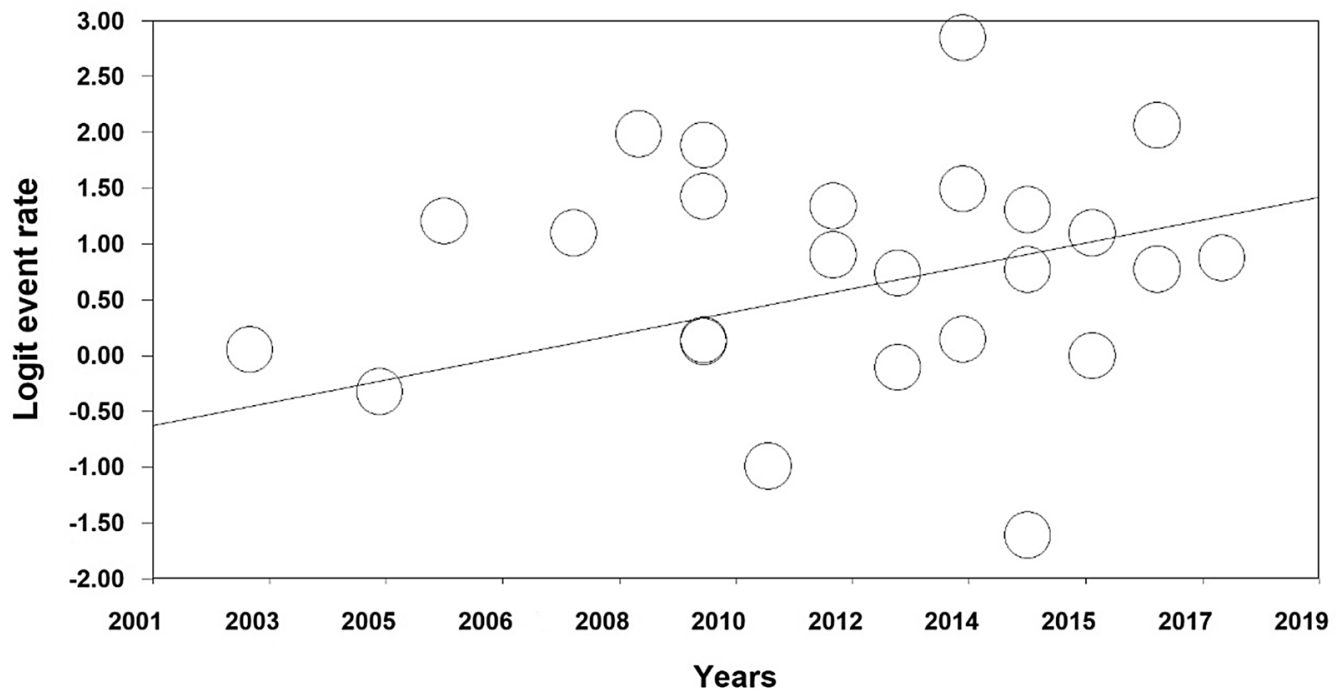

Fig. 5 Meta-regression diagram of the prevalence of sexual dysfunction in women with type 2 diabetes by sample size and year of publication

these indices, and these values were statistically significant in all studies (Table 2) $(\mathrm{P}<0.05)$.

Therefore, in order to equalize the values of each of the indices of sexual dysfunction in women with type 2 diabetes and their control group, the meta-analysis was used so as to evaluate the overall mean scores while reviewing all studies. Based on the results of meta-analysis (Figs. 6, $7,8,9,10$ and 11), FSFIs scores (expressed as mean \pm SD in $t$ test analysis) in case and control groups were as follows: Desire, arousal, lubrication, satisfaction, orgasm, and pain in the case and control groups were respectively $3.4 \pm 0.31$ and $4.9 \pm 0.7$ (Fig. 6), $5.6 \pm 2.1$ and $7.3 \pm 1.91$
(Fig. 7), $5.9 \pm 1.47$ and $5.4 \pm 5.1$ (Fig. 8), $6.3 \pm 4.2$ and $6.3 \pm 1.9$ (Fig. 9), $5.4 \pm 0.08$ and $5.5 \pm 1.5$ (Fig. 10), $3.28 \pm 0.19$ and $5.1 \pm 0.36$ (Fig. 11). There was a significant difference between the case and control groups in all studies in terms of FSFI indices and the mean scores were lower in the case group (women with diabetes type $2)$ than the control group $(\mathrm{P}<0.05)$.

\section{Discussion}

Sexual dysfunction is defined as a person's inability to engage in the desired sexual intercourse. This disorder can be a symptom of problems with biological origin 
Table 2 Specifications of studies entered the study (Female Sexual Function Index)

\begin{tabular}{|c|c|c|c|c|c|c|}
\hline $\begin{array}{l}\text { Female Sexual } \\
\text { Function Index }\end{array}$ & Studies [references] & $\mathrm{N}$ & Case (mean \pm SD) & $\mathrm{N}$ & Control (mean \pm SD) & P value \\
\hline \multirow[t]{10}{*}{ Desire } & Shi et al. [49] & 106 & $2.43 \pm 0.99$ & 100 & $3.04 \pm 1.04$ & 0.000 \\
\hline & Nowosielski et al. [48] & 133 & $3.45 \pm 1.24$ & 109 & $3.91 \pm 1.13$ & 0.000 \\
\hline & Mezones et al. [43] & 36 & $2.6 \pm 1.4$ & 36 & $3.8 \pm 1.1$ & 0.000 \\
\hline & Ogbera et al. [44] & 58 & $2.3 \pm 0.9$ & 38 & $3 \pm 0.6$ & 0.000 \\
\hline & Sharifiaghdas et al. [50] & 45 & $32 \pm 1.1$ & 90 & $47 \pm 56.5$ & 0.000 \\
\hline & Afshari et al. [75] & 106 & $3.34 \pm 1.37$ & 128 & $3.69 \pm 1.19$ & 0.000 \\
\hline & Ammar et al. [58] & 30 & $2.86 \pm 1.2$ & 30 & $4 \pm 1$ & 0.000 \\
\hline & Mazzilli et al. [57] & 24 & $5.4 \pm 1.2$ & 45 & $6.8 \pm 1.7$ & 0.000 \\
\hline & Bak et al. [60] & 101 & $6.8 \pm 3.03$ & 89 & $8.9 \pm 1.08$ & 0.000 \\
\hline & Li et al. [59] & 184 & $2.38 \pm 1.06$ & 146 & $2.82 \pm 1.17$ & 0.000 \\
\hline \multirow[t]{12}{*}{ Arousal } & Shi et al. [49] & 106 & $2.54 \pm 1.5$ & 100 & $3.26 \pm 1.31$ & 0.000 \\
\hline & Nowosielski et al. [48] & 133 & $3.75 \pm 1.76$ & 109 & $4.4 \pm 1.35$ & 0.000 \\
\hline & Yencilk et al. [34] & 62 & $3.09 \pm 1.81$ & 50 & $5.47 \pm 1.95$ & 0.000 \\
\hline & Mezones et al. [43] & 36 & $3.5 \pm 1.9$ & 36 & $4.7 \pm 0.8$ & 0.000 \\
\hline & Veronelli et al. [76] & 28 & $3.4 \pm 0.39$ & 36 & $5 \pm 0.16$ & 0.000 \\
\hline & Ogbera et al. [44] & 58 & $2 \pm 1.5$ & 38 & $3.2 \pm 1.5$ & 0.000 \\
\hline & Sharifiaghdas et al. [50] & 45 & $38 \pm 84.4$ & 90 & $61 \pm 67$ & 0.000 \\
\hline & Afshari et al. [75] & 106 & $3.66 \pm 1.37$ & 128 & $3.79 \pm 1.39$ & 0.000 \\
\hline & Ammar et al. [58] & 30 & $3.13 \pm 0.7$ & 30 & $4.3 \pm 0.8$ & 0.000 \\
\hline & Cortelazzi et al. [31] & 48 & $4.1 \pm 0.16$ & 61 & $4.5 \pm 0.11$ & 0.000 \\
\hline & Naghavi et al. [77] & 50 & $22.8 \pm 0.5$ & 40 & $15.2 \pm 0.1$ & 0.000 \\
\hline & Li et al. [59] & 184 & $2.47 \pm 1.53$ & 146 & $3.07 \pm 1.42$ & 0.000 \\
\hline \multirow[t]{13}{*}{ Lubrication } & Shi et al. [49] & 106 & $3.25 \pm 1.89$ & 100 & $4.22 \pm 1.72$ & 0.000 \\
\hline & Nowosielski et al. [48] & 133 & $4.53 \pm 1.72$ & 109 & $5.01 \pm 1.45$ & 0.000 \\
\hline & Esposito et al. [45] & 322 & $2.5 \pm 0.9$ & 273 & $3.4 \pm 1$ & 0.000 \\
\hline & Yencilk et al. [34] & 62 & $4.31 \pm 2.2$ & 50 & $5.68 \pm 1.19$ & 0.000 \\
\hline & Olarinoye et al. [78] & 52 & $2.51 \pm 2.07$ & 39 & $5 \pm 1.91$ & 0.000 \\
\hline & Erol et al. [40] & 72 & $4.3 \pm 1$ & 60 & $4.6 \pm 0.6$ & 0.000 \\
\hline & Mezones et al. [43] & 36 & $3.2 \pm 1.9$ & 36 & $4.5 \pm 1.3$ & 0.000 \\
\hline & Veronelli et al. [76] & 28 & $3.6 \pm 0.46$ & 36 & $5.6 \pm 0.11$ & 0.000 \\
\hline & Afshari et al. [75] & 106 & $3.62 \pm 1.25$ & 128 & $4.05 \pm 1.39$ & 0.000 \\
\hline & Ammar et al. [58] & 30 & $4.3 \pm 0.6$ & 30 & $5.2 \pm 0.5$ & 0.000 \\
\hline & Cortelazzi et al. [31] & 48 & $4.6 \pm 0.17$ & 61 & $5 \pm 0.12$ & 0.000 \\
\hline & Naghavi et al. [77] & 50 & $22.4 \pm 0.6$ & 40 & $15.2 \pm 0.1$ & 0.000 \\
\hline & Li et al. [59] & 184 & $3.14 \pm 1.86$ & 146 & $3.88 \pm 1.68$ & 0.000 \\
\hline \multirow[t]{13}{*}{ Orgasm } & Shi et al. [49] & 106 & $2.89 \pm 1.76$ & 100 & $3.76 \pm 1.66$ & 0.000 \\
\hline & Nowosielski et al. [48] & 133 & $4.45 \pm 1.23$ & 109 & $4.78 \pm 1.21$ & 0.000 \\
\hline & Yencilk et al. [34] & 62 & $3.91 \pm 2.7$ & 50 & $5.01 \pm 1.96$ & 0.000 \\
\hline & Olarinoye et al. [78] & 52 & $2.02 \pm 1.41$ & 39 & $3.22 \pm 1.38$ & 0.000 \\
\hline & Erol et al. [40] & 72 & $3.5 \pm 1$ & 60 & $4.5 \pm 0.5$ & 0.000 \\
\hline & Mezones et al. [43] & 36 & $3.2 \pm 1.8$ & 36 & $4.5 \pm 1.1$ & 0.000 \\
\hline & Veronelli et al. [76] & 28 & $3.5 \pm 0.45$ & 36 & $5.4 \pm 0.12$ & 0.000 \\
\hline & Afshari et al. [75] & 106 & $3.68 \pm 1.42$ & 128 & $3.86 \pm 1.47$ & 0.000 \\
\hline & Ammar et al. [58] & 30 & $4 \pm 1.1$ & 30 & $5.17 \pm 0.6$ & 0.000 \\
\hline & Cortelazzi et al. [31] & 48 & $4.5 \pm 0.15$ & 61 & $5 \pm 0.11$ & 0.000 \\
\hline & Naghavi et al. [77] & 50 & $25.6 \pm 0.3$ & 40 & $15.1 \pm 0.1$ & 0.000 \\
\hline & Bak et al. [60] & 101 & $6.8 \pm 3.03$ & 89 & $8.9 \pm 1.08$ & 0.000 \\
\hline & Li et al. [59] & 184 & $2.78 \pm 1.78$ & 146 & $3.48 \pm 1.6$ & 0.000 \\
\hline
\end{tabular}


Table 2 (continued)

\begin{tabular}{|c|c|c|c|c|c|c|}
\hline $\begin{array}{l}\text { Female Sexual } \\
\text { Function Index }\end{array}$ & Studies [references] & $\mathrm{N}$ & Case (mean \pm SD) & $\mathrm{N}$ & Control (mean \pm SD) & P value \\
\hline \multirow[t]{10}{*}{ Satisfaction } & Shi et al. [49] & 106 & $3.63 \pm 1.25$ & 100 & $4.27 \pm 1.33$ & 0.000 \\
\hline & Nowosielski et al. [48] & 133 & $4.59 \pm 1.09$ & 109 & $4.94 \pm 1.11$ & 0.000 \\
\hline & Yencilk et al. [34] & 62 & $4.51 \pm 1.88$ & 50 & $5.34 \pm 1.64$ & 0.000 \\
\hline & Erol et al. [40] & 72 & $3.4 \pm 1$ & 60 & $4.3 \pm 0.6$ & 0.000 \\
\hline & Mezones et al. [43] & 36 & $3.8 \pm 1.3$ & 36 & $4.8 \pm 0.9$ & 0.000 \\
\hline & Ogbera et al. [44] & 58 & $2.9 \pm 2.2$ & 38 & $4 \pm 1.9$ & 0.000 \\
\hline & Afshari et al. [75] & 106 & $4.01 \pm 1.33$ & 128 & $4.08 \pm 1.36$ & 0.000 \\
\hline & Ammar et al. [58] & 30 & $4.13 \pm 0.8$ & 30 & $5.25 \pm 1.1$ & 0.000 \\
\hline & Naghavi et al. [77] & 50 & $24.2 \pm 0.2$ & 40 & $13.7 \pm 0.1$ & 0.000 \\
\hline & Bak et al. [60] & 101 & $8.1 \pm 3.5$ & 89 & $12.8 \pm 1.65$ & 0.000 \\
\hline \multirow[t]{6}{*}{ Pain } & Yencilk et al. [34] & 62 & $3.14 \pm 1.92$ & 50 & $4.92 \pm 2.01$ & 0.000 \\
\hline & Olarinoye et al. [78] & 52 & $2.43 \pm 2.04$ & 39 & $5 \pm 1.87$ & 0.000 \\
\hline & Mezones et al. [43] & 36 & $3.1 \pm 1.7$ & 36 & $4.6 \pm 1.3$ & 0.000 \\
\hline & Veronelli et al. [76] & 28 & $3.7 \pm 0.49$ & 36 & $5.3 \pm 0.24$ & 0.000 \\
\hline & Sharifiaghdas et al. [50] & 45 & $4 \pm 8.9$ & 90 & $23 \pm 25.3$ & 0.000 \\
\hline & Li et al. [59] & 184 & $3.65 \pm 1.94$ & 146 & $4.14 \pm 1.77$ & 0.000 \\
\hline
\end{tabular}

(biogenic) or intra-psychological or interpersonal conflicts (psychogenic) or a combination of these factors, and any type of stress, emotional disturbances, or lack of knowledge about physiology and sexual function can have a negative effect on the sexual function [63]. Results of various studies revealed that $40 \%$ of couples suffer from sexual disorders or relative dissatisfaction with such disorders [64]. Diabetic Individuals are also susceptible to various types of physical and mental disorders and one of the most important neglected care is sexual dysfunction in these patients [65]. Sexual health is an important part of diabetes care, which is particularly neglected in women [66, 67]. Decreased nitric oxide production due to vascular dysfunctions decreases vascular vaginal relaxation and vascular, neurological, and psychiatric disorders are the main causes of reduced desire, vaginal discharge and lubrication, arousal, and orgasm in women with diabetes [67]. Ovarian hormones have an effect on sexual desire; therefore, a factor such as diabetes can disrupt the secretion of these hormones and thus affects the sexual desire of women with diabetes [66]. Diabetes also has a negative effect on the secretion of the endocrine glands at the beginning the vagina and may cause vaginal dryness and irritation, and the couples may experience a painful intercourse [69]; however, another cause of painful intercourse include pelvic, virginal, uterine, and tube infections that may occur more frequently in women with diabetes are $[68,69]$; therefore, diabetic women are more likely to experience decreased sexual desire, disrupted ovulation, early menopause, and even infertility than non-infected women [64-69] and these factors showed the importance of control and attention to women with type 2 diabetes.

Nappi et al. reported three critical physiologic requirements, including intact sex steroids, autonomic/somatic nerves, and arterial inflow/perfusion pressure to women's genital organs play fundamental roles in maintaining women's sexual function [79] and Maseroli et al. reported Clitoral vascular resistance is positively associated with MetS, decreased sexual arousal, body image concerns, and increased somatized anxiety symptoms [80].

Results of the present study and the review of 3892 individuals aged 18-70 years, the overall prevalence of sexual dysfunction in women with type 2 diabetes was $68.6 \%$ based on meta-analysis. Scores of all FSFI (sexual desire, arousal, vaginal lubrication, orgasms, satisfaction, and pain) in diabetic women were lower than nondiabetic women. In order to investigate the effects of potentially effective factors on the heterogeneity of the prevalence of sexual dysfunction in women with type 2 diabetes, meta-regression test was applied to two factors of sample size and year of study, With an increase in the sample size, the overall prevalence of sexual dysfunction is reduced in women with Type 2 diabetes, with an increase in the year of the research, the overall prevalence of sexual dysfunction in women with type 2 diabetes is increased, which was also statistically significant. 
Case Desire

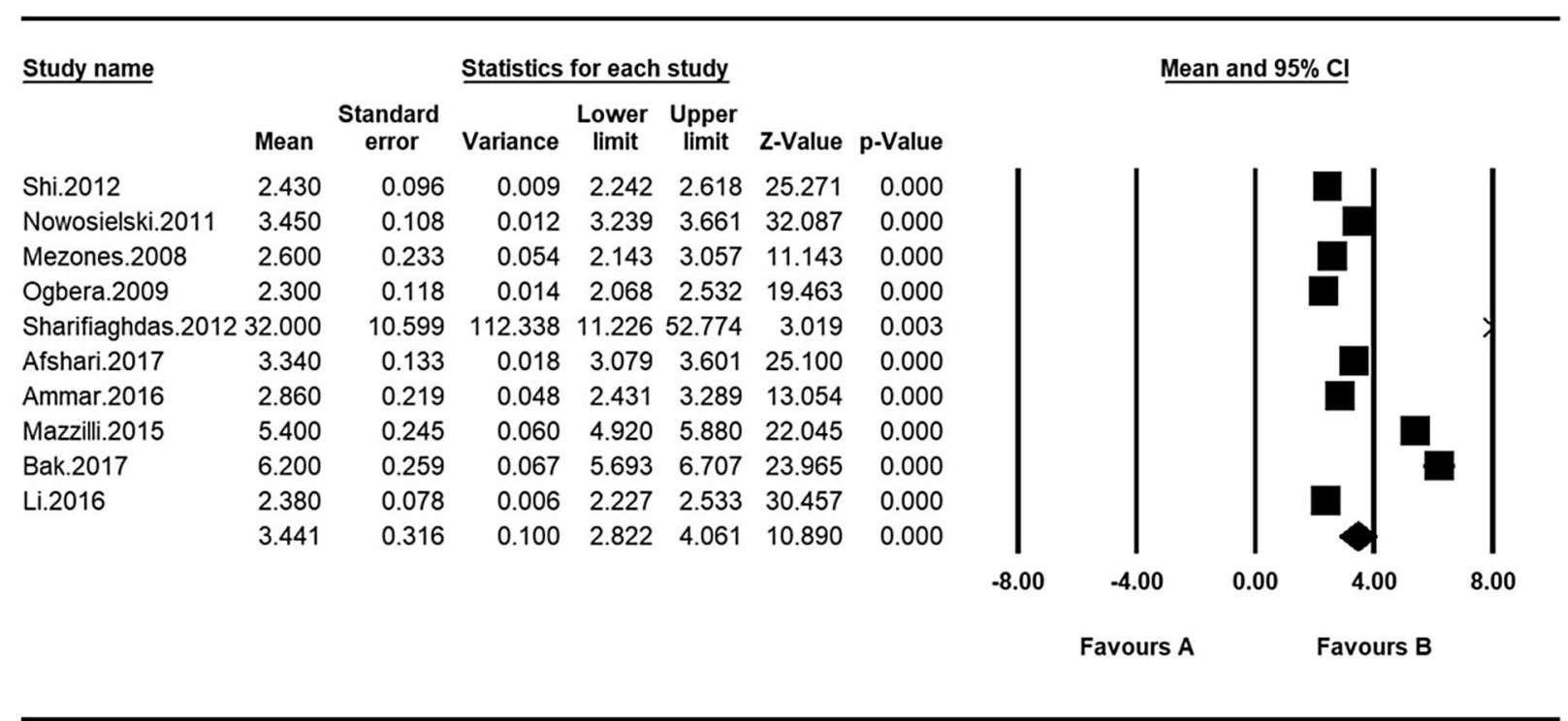

Meta Analysis

Control Desire

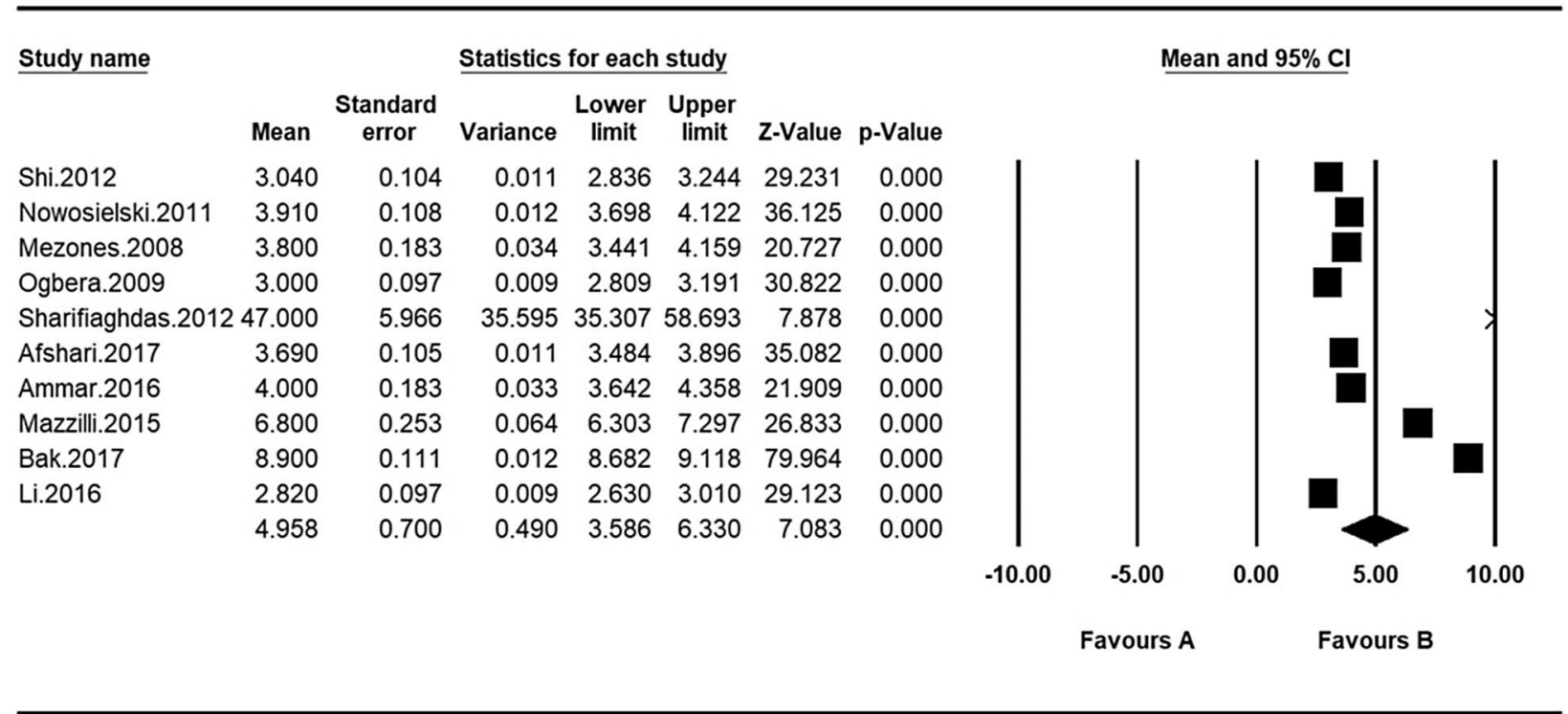

Meta Analysis

Fig. 6 Meta-analysis of mean score of desire index in case and control groups based on the random model

Results of a study in the United States reported that $43 \%$ of American women aged 18-59 years have sexual concerns [68]; however, Dennerstein et al. [69] reported that $42-88 \%$ of women suffer from sexual dysfunction during menstrual cycle. Pontiroli et al., in their systematic review and meta-analysis, reported that the chance for people with type 2 diabetes to develop sexual dysfunction is $2.4 \%$ more than that of non-affected people, whereas women with type 2 diabetes are 2 times more likely to have sexual dysfunction than non-affected women [70]. Various studies reported higher prevalence for sexual dysfunction in the diabetic individuals in comparison with the general population, and this factor is considered as one of the most important factors affecting the marital satisfaction in people with sexual dysfunction [71]. Meeking 
Case Arousal

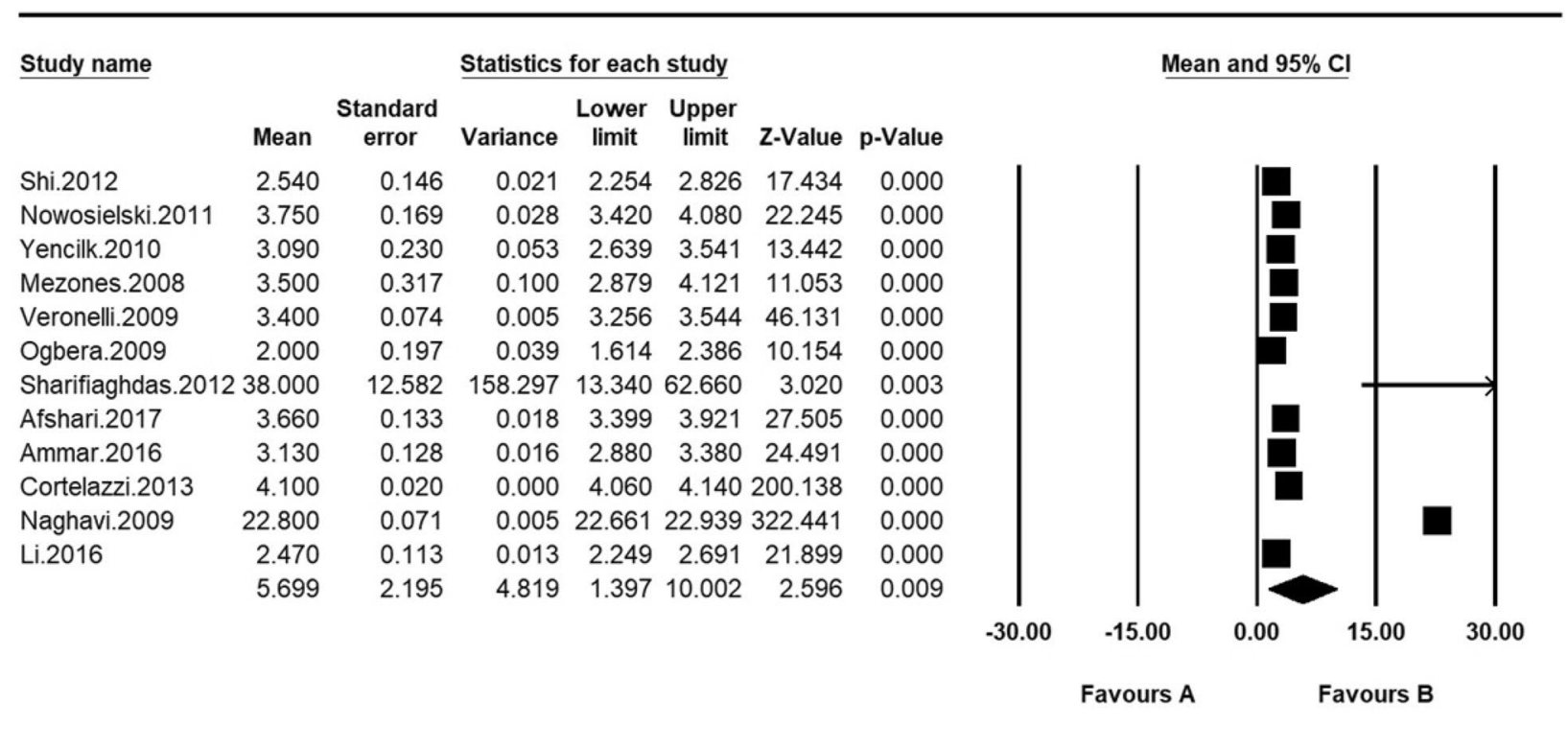

Meta Analysis

Control Arousal

\begin{tabular}{|c|c|c|c|c|c|c|c|}
\hline \multirow[t]{2}{*}{ Study name } & \multicolumn{7}{|c|}{ Statistics for each study } \\
\hline & Mean & $\begin{array}{l}\text { Standard } \\
\text { error }\end{array}$ & Variance & $\begin{array}{l}\text { Lower } \\
\text { limit }\end{array}$ & $\begin{array}{l}\text { Upper } \\
\text { limit }\end{array}$ & Z-Value & p-Val \\
\hline Shi.2012 & 3.260 & 0.131 & 0.017 & 3.003 & 3.517 & 24.885 & 0.0 \\
\hline Nowosielski.2011 & 4.410 & 0.129 & 0.017 & 4.157 & 4.663 & 34.105 & 0.0 \\
\hline Yencilk.2010 & 5.470 & 0.276 & 0.076 & 4.929 & 6.011 & 19.835 & 0.000 \\
\hline Mezones.2008 & 4.700 & 0.133 & 0.018 & 4.439 & 4.961 & 35.250 & 0.000 \\
\hline Veronelli.2009 & 5.000 & 0.027 & 0.001 & 4.948 & 5.052 & 187.500 & 0.000 \\
\hline Ogbera.2009 & 3.200 & 243 & 0.059 & 2.723 & 3.677 & 13.151 & 0.00 \\
\hline \multicolumn{2}{|c|}{ Sharifiaghdas.2012 61.000} & 7.062 & 49.878 & 47.158 & 74.842 & 8.637 & 0.000 \\
\hline Afshari.2017 & 3.790 & 0.123 & 0.015 & 3.549 & 4.031 & 30.848 & 0.00 \\
\hline Ammar.2016 & 4.300 & 0.146 & 0.021 & 4.014 & 4.586 & 29.440 & 0.00 \\
\hline Cortelazzi.2013 & 4.500 & 0.014 & 0.000 & 4.472 & 4.528 & 319.510 & 0.00 \\
\hline Naghavi.2009 & 15.200 & 0.016 & 0.000 & 15.169 & 15.231 & 961.332 & 0.00 \\
\hline \multirow[t]{2}{*}{ Li.2016 } & 3.070 & 0.118 & 0.014 & 2.840 & 3.300 & 26.123 & 0.00 \\
\hline & 7.398 & 1.912 & 3.655 & 3.651 & 11.145 & 3.869 & 0.0 \\
\hline
\end{tabular}

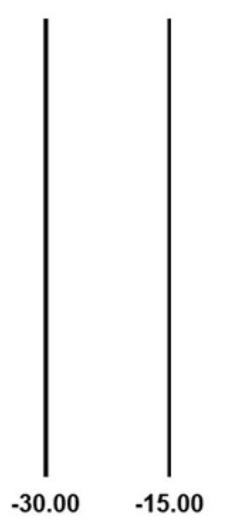

Favours A
Mean and $95 \% \mathrm{Cl}$

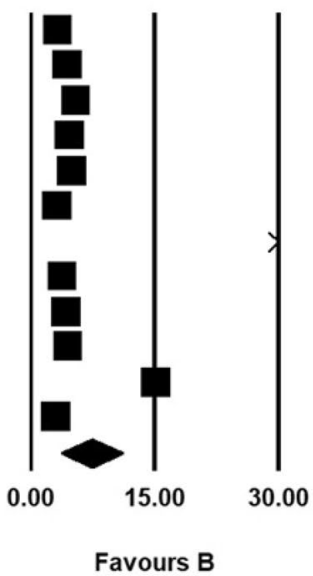

\section{Meta Analysis}

Fig. 7 Meta-analysis of the mean score of the arousal index in case and control groups based on the random model

et al. [72] reported a decrease in sexual desire, vaginal lubrication, satisfaction, and orgasm in $64 \%, 70 \%$, $36 \%$, and $47 \%$ of patients, respectively. In another study on patients with type 2 diabetes, Schriener-Engel et al. [73] reported a decrease in sexual desire, vaginal lubrication, and orgasm in patients with type 2 diabetes; while other studies showed the negative impact of type 2 diabetes on sexual desire, sexual satisfaction, 


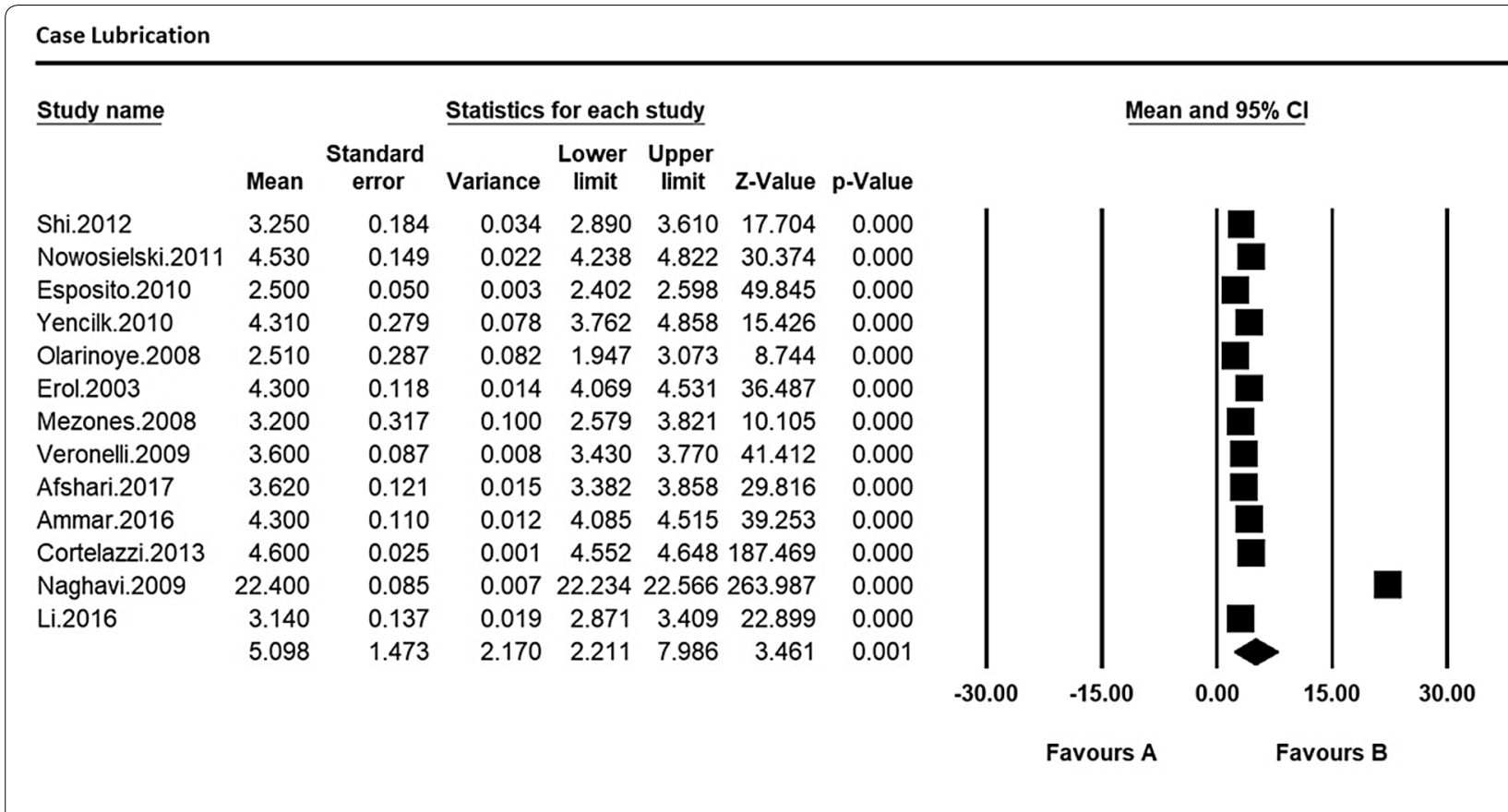

Meta Analysis

Control Lubrication

\begin{tabular}{|c|c|c|c|c|c|c|c|c|c|c|c|c|}
\hline \multirow[t]{2}{*}{ Study name } & \multicolumn{7}{|c|}{ Statistics for each study } & \multicolumn{5}{|c|}{ Mean and $95 \% \mathrm{Cl}$} \\
\hline & Mean & $\begin{array}{l}\text { Standard } \\
\text { error }\end{array}$ & Variance & $\begin{array}{l}\text { Lower } \\
\text { limit }\end{array}$ & $\begin{array}{l}\text { Upper } \\
\text { limit }\end{array}$ & Z-Value & p-Value & & & & & \\
\hline Shi.2012 & 4.220 & 0.172 & 0.030 & 3.883 & 4.557 & 24.535 & 0.000 & & & & & $\mid$ \\
\hline Nowosielski.2011 & 5.010 & 0.139 & 0.019 & 4.738 & 5.282 & 36.073 & 0.000 & & & & & \\
\hline Esposito. 2010 & 3.400 & 0.061 & 0.004 & 3.281 & 3.519 & 56.177 & 0.000 & & & & & \\
\hline Yencilk.2010 & 5.680 & 0.168 & 0.028 & 5.350 & 6.010 & 33.751 & 0.000 & & & & & \\
\hline Olarinoye.2008 & 5.000 & 0.306 & 0.094 & 4.401 & 5.599 & 16.348 & 0.000 & & & & & \\
\hline Erol.2003 & 4.600 & 0.077 & 0.006 & 4.448 & 4.752 & 59.386 & 0.000 & & & & & \\
\hline Mezones.2008 & 4.500 & 0.217 & 0.047 & 4.075 & 4.925 & 20.769 & 0.000 & & & & & \\
\hline Veronelli.2009 & 5.600 & 0.018 & 0.000 & 5.564 & 5.636 & 305.455 & 0.000 & & & & & \\
\hline Afshari.2017 & 4.050 & 0.123 & 0.015 & 3.809 & 4.291 & 32.964 & 0.000 & & & & & \\
\hline Ammar.2016 & 5.200 & 0.091 & 0.008 & 5.021 & 5.379 & 56.963 & 0.000 & & & & & \\
\hline Cortelazzi.2013 & 5.000 & 0.015 & 0.000 & 4.970 & 5.030 & 325.427 & 0.000 & & & & & \\
\hline Naghavi.2009 & 15.200 & 0.016 & 0.000 & 15.169 & 15.231 & 961.332 & 0.000 & & & & & \\
\hline \multirow[t]{4}{*}{ Li.2016 } & 3.880 & 0.139 & 0.019 & 3.607 & 4.153 & 27.906 & 0.000 & & & & & \\
\hline & 5.488 & 1.571 & 2.468 & 2.409 & 8.567 & 3.493 & 0.000 & & & & & \\
\hline & & & & & & & & -30.00 & -15.00 & 0.00 & 15.00 & 30.00 \\
\hline & & & & & & & & & Favours A & & avours B & \\
\hline
\end{tabular}

Meta Analysis

Fig. 8 Meta-analysis of the mean score of the lubrication index in case and control groups based on the random model

lubrication, and orgasm. Enzlin et al. [74] also reports that $35 \%$ of women with Type 2 diabetes have orgasmic disorder. Results of this study indicate very high prevalence of sexual dysfunction in women with type 2 diabetes and it is necessary to pay attention to the correlation between sexual function and marital 


\section{Case Satisfaction}

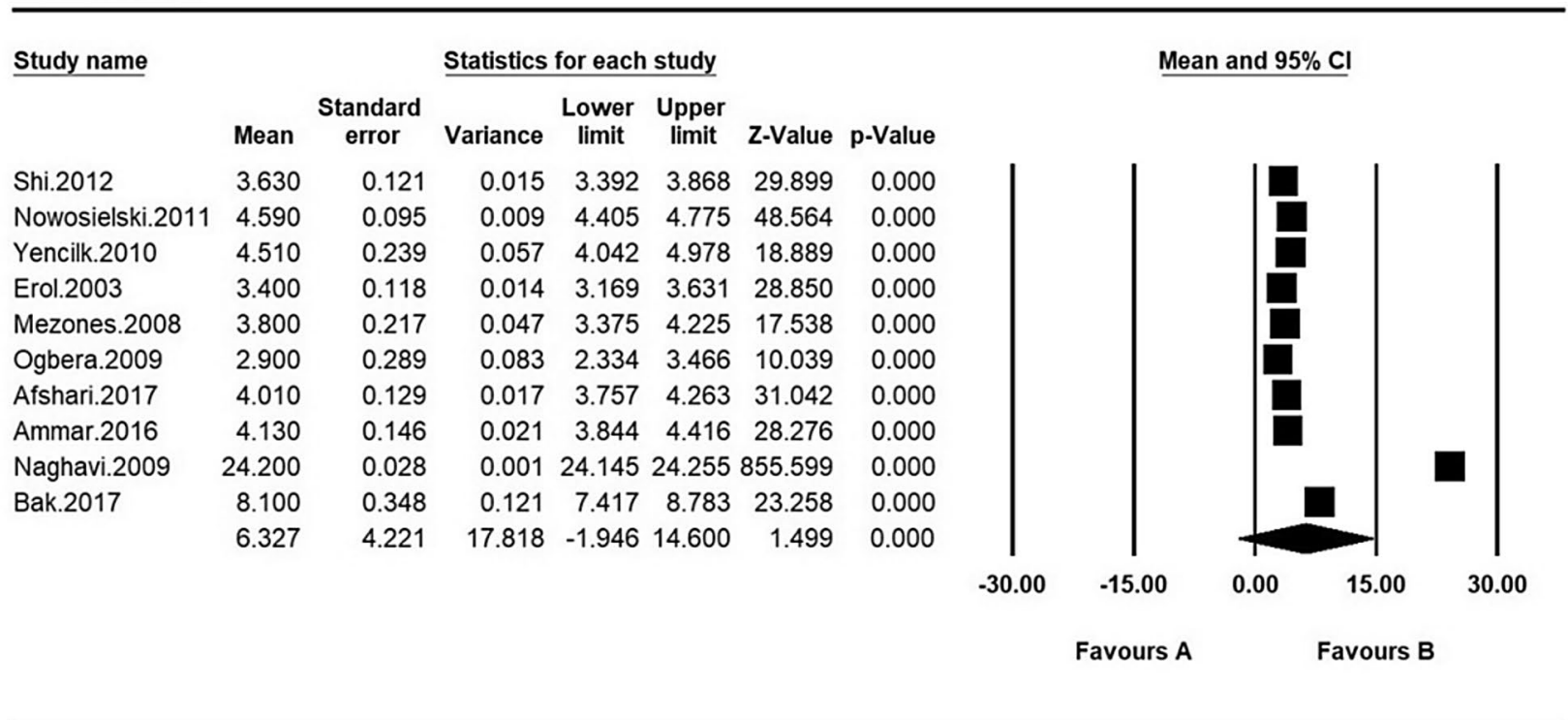

Meta Analysis

Control Satisfaction

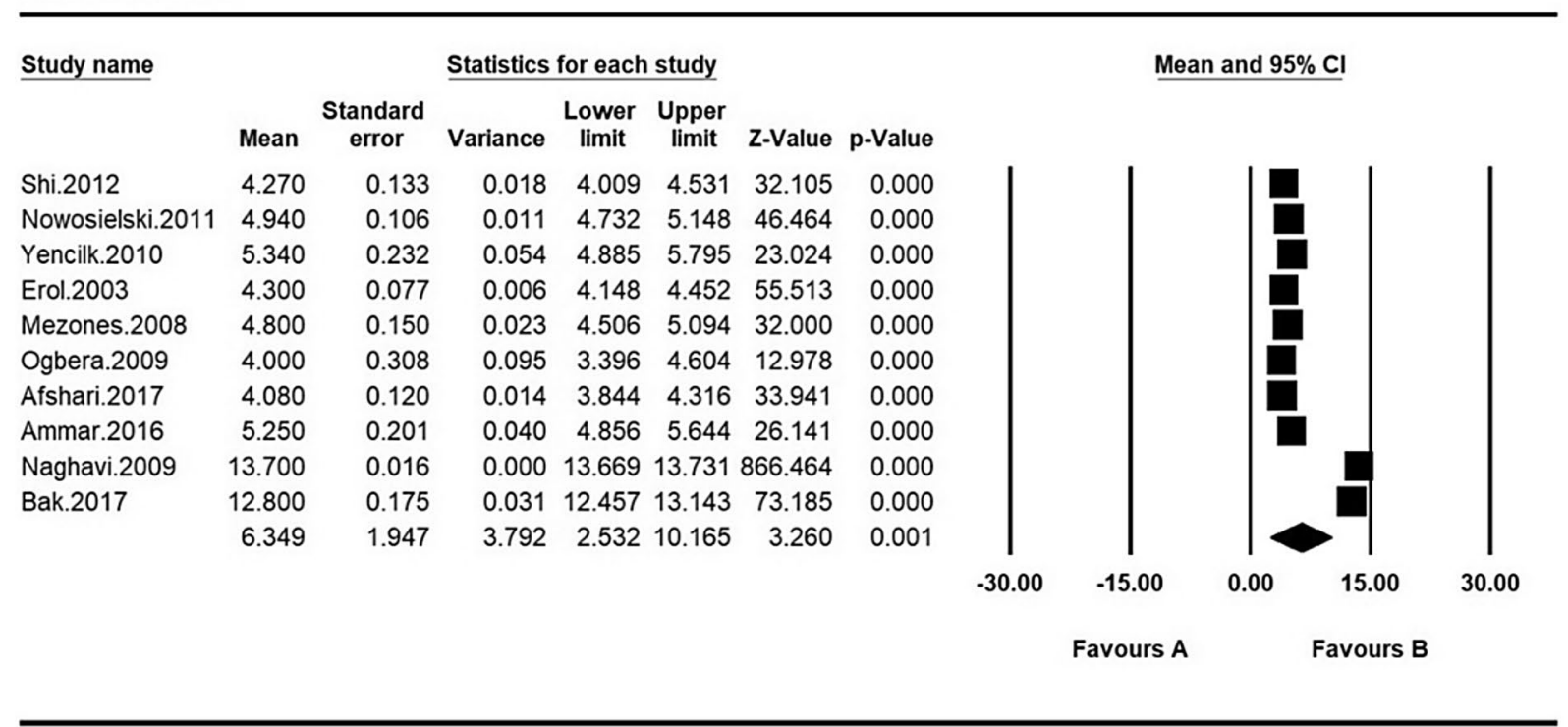

Fig. 9 Meta-analysis of mean satisfaction score in case and control groups based on the random model

satisfaction. It is also very essential to pay attention to quality of life in women with diabetes so that health policy-makers, physicians, and healthcare providers to place this disorder among the most important and significant disorders in women with type 2 diabetes and to seek out a low prevalence of this disorder through psychological counseling and adopting treatment procedures so as to improve the quality of their marital life and prevent disorders and mental diseases in women.

\section{Limitations}

The most important limitation of the present study is the lack of access to the full text and low quality of some of the studies reviewed. 


\begin{tabular}{|c|c|c|c|c|c|c|c|c|c|c|c|}
\hline \multicolumn{12}{|l|}{ Case Orgasm } \\
\hline \multirow[t]{2}{*}{ Study name } & \multicolumn{7}{|c|}{ Statistics for each study } & \multicolumn{4}{|c|}{ Mean and $95 \% \mathrm{Cl}$} \\
\hline & Mean & $\begin{array}{l}\text { Standard } \\
\text { error }\end{array}$ & Variance & $\begin{array}{c}\text { Lower } \\
\text { limit }\end{array}$ & $\begin{array}{c}\text { Upper } \\
\text { limit }\end{array}$ & Z-Value & p-Value & & & & \\
\hline Shi.2012 & 2.890 & 0.171 & 0.029 & 2.555 & 3.225 & 16.906 & 0.000 & & & 1 & 1 \\
\hline Nowosielski.2011 & 4.450 & 0.107 & 0.011 & 4.241 & 4.659 & 41.723 & 0.000 & & & & \\
\hline Yencilk.2010 & 3.910 & 0.343 & 0.118 & 3.238 & 4.582 & 11.403 & 0.000 & & & & \\
\hline Olarinoye. 2008 & 2.020 & 0.196 & 0.038 & 1.637 & 2.403 & 10.331 & 0.000 & & & & \\
\hline Erol.2003 & 3.500 & 0.118 & 0.014 & 3.269 & 3.731 & 29.698 & 0.000 & & & & \\
\hline Mezones.2008 & 3.200 & 0.300 & 0.090 & 2.612 & 3.788 & 10.667 & 0.000 & & & & \\
\hline Veronelli.2009 & 3.500 & 0.085 & 0.007 & 3.333 & 3.667 & 41.156 & 0.000 & & & & \\
\hline Afshari.2017 & 3.680 & 0.138 & 0.019 & 3.410 & 3.950 & 26.682 & 0.000 & & & & \\
\hline Ammar.2016 & 4.000 & 0.201 & 0.040 & 3.606 & 4.394 & 19.917 & 0.000 & & & & \\
\hline Cortelazzi.2013 & 4.500 & 0.022 & 0.000 & 4.458 & 4.542 & 207.846 & 0.000 & & & & \\
\hline Naghavi.2009 & 25.600 & 0.042 & 0.002 & 25.517 & 25.683 & 603.398 & 0.000 & & & & \\
\hline Bak.2017 & 6.800 & 0.301 & 0.091 & 6.209 & 7.391 & 22.554 & 0.000 & & & & \\
\hline \multirow[t]{4}{*}{ Li.2016 } & 2.780 & 0.131 & 0.017 & 2.523 & 3.037 & 21.185 & 0.000 & & & & \\
\hline & 5.449 & 3.085 & 9.514 & -0.597 & 11.494 & 1.767 & 0.000 & & & & \\
\hline & & & & & & & & -30.00 & -15.00 & 15.00 & 30.00 \\
\hline & & & & & & & & & Favours A & Favours B & \\
\hline
\end{tabular}

Meta Analysis

Control Orgasm

\begin{tabular}{|c|c|c|c|c|c|c|c|c|c|c|c|}
\hline \multirow[t]{2}{*}{ Study name } & \multicolumn{7}{|c|}{ Statistics for each study } & \multicolumn{4}{|c|}{ Mean and $95 \% \mathrm{Cl}$} \\
\hline & Mean & $\begin{array}{l}\text { Standard } \\
\text { error }\end{array}$ & Variance & $\begin{array}{l}\text { Lower } \\
\text { limit }\end{array}$ & $\begin{array}{l}\text { Upper } \\
\text { limit }\end{array}$ & Z-Value & p-Value & & & & \\
\hline Shi.2012 & 3.760 & 0.166 & 0.028 & 3.435 & 4.085 & 22.651 & 0.000 & & & 列 & 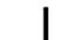 \\
\hline Nowosielski.2011 & 4.780 & 0.116 & 0.013 & 4.553 & 5.007 & 41.244 & 0.000 & & & & \\
\hline Yencilk.2010 & 5.010 & 0.277 & 0.077 & 4.467 & 5.553 & 18.075 & 0.000 & & & & \\
\hline Olarinoye. 2008 & 3.230 & 0.221 & 0.049 & 2.797 & 3.663 & 14.617 & 0.000 & & & & \\
\hline Erol.2003 & 4.500 & 0.065 & 0.004 & 4.373 & 4.627 & 69.714 & 0.000 & & & & \\
\hline Mezones.2008 & 4.500 & 0.183 & 0.034 & 4.141 & 4.859 & 24.545 & 0.000 & & & & \\
\hline Veronelli.2009 & 5.400 & 0.020 & 0.000 & 5.361 & 5.4392 & 270.000 & 0.000 & & & & \\
\hline Afshari.2017 & 3.860 & 0.130 & 0.017 & 3.605 & 4.115 & 29.708 & 0.000 & & & & \\
\hline Ammar.2016 & 5.170 & 0.110 & 0.012 & 4.955 & 5.385 & 47.195 & 0.000 & & & & \\
\hline Cortelazzi.2013 & 5.000 & 0.014 & 0.000 & 4.972 & 5.0283 & 355.011 & 0.000 & & & & \\
\hline Naghavi.2009 & 15.100 & 0.016 & 0.000 & 15.069 & $15.131 \varsigma$ & 955.008 & 0.000 & & & & \\
\hline Bak.2017 & 8.900 & 0.114 & 0.013 & 8.676 & 9.124 & 77.743 & 0.000 & & & & \\
\hline \multirow[t]{4}{*}{ Li.2016 } & 3.480 & 0.236 & 0.056 & 3.018 & 3.942 & 14.752 & 0.000 & & & & \\
\hline & 5.592 & 1.583 & 2.506 & 2.490 & 8.695 & 3.533 & 0.000 & & & & \\
\hline & & & & & & & & -30.00 & -15.00 & 15.00 & 30.00 \\
\hline & & & & & & & & & Favours A & Favours B & \\
\hline
\end{tabular}

Meta Analysis

Fig. 10 Meta-analysis of the mean orgasm score in case and control groups based on the random model 


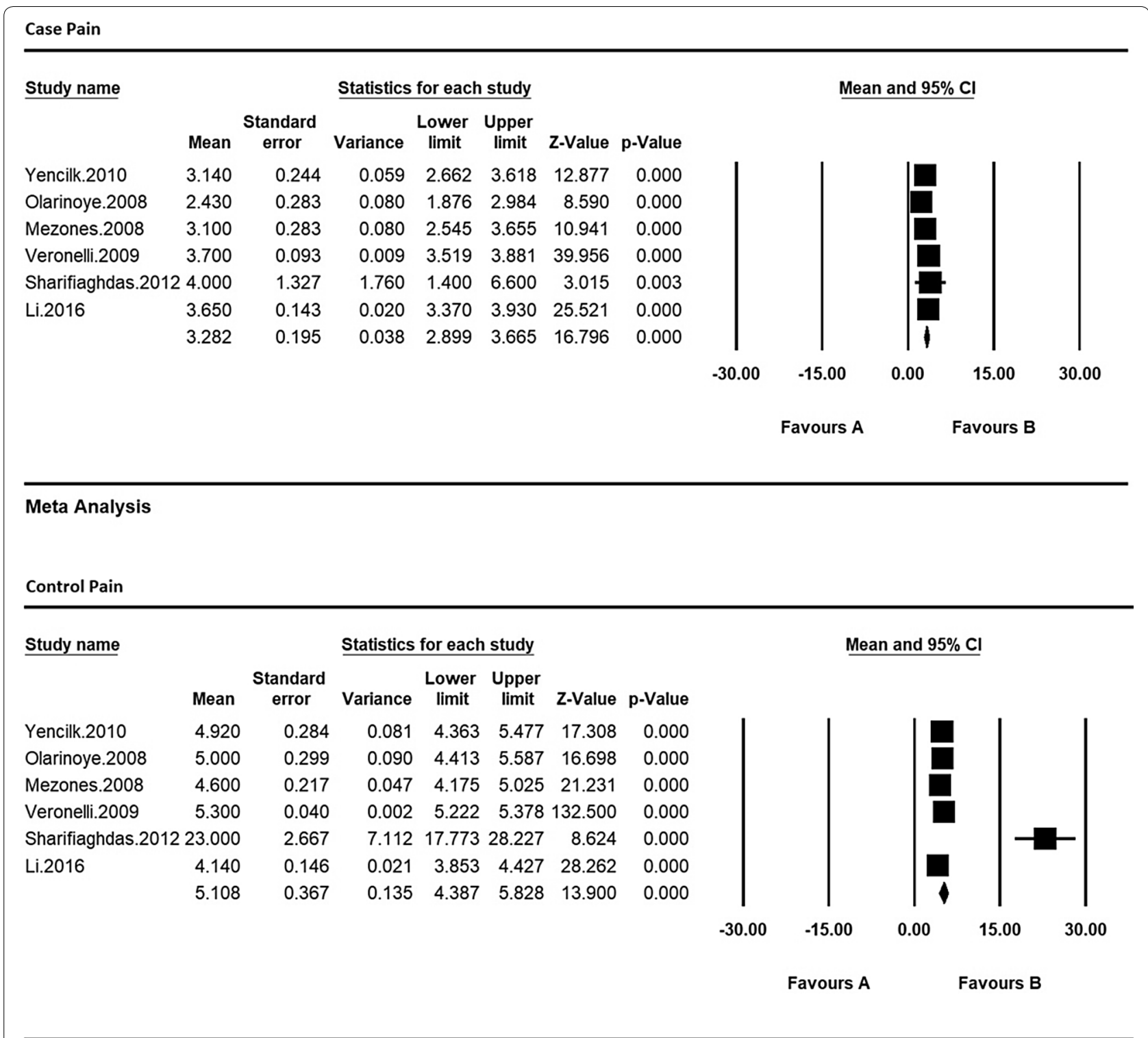

\section{Meta Analysis}

Fig. 11 Meta-analysis of the mean pain score in case and control groups based on the random model

\section{Conclusion}

Regarding the high prevalence of sexual dysfunction in women with type 2 diabetes, it is essential for health policy-makers to take effective control as well as treatment measures, including periodic sexual care, for women with type 2 diabetes.

\section{Abbreviations}

WHO: World Health Organization; FSFI: Female Sexual Function Index; SID: Scientific Information Database; STROBE: Strengthening the Reporting of Observational Studies in Epidemiology for cross-sectional Study; PRISMA:

Preferred Reporting Items for Systematic Reviews and Meta-Analysis.
Acknowledgements

The authors thank the faculty members of the Faculty of Nursing and Midwifery, Kermanshah University of Medical Sciences.

Authors' contributions

$\mathrm{RJ}$ and NS contributed to the design, MM statistical analysis, participated in most of the study steps. NS and RJ prepared the manuscript. RJ and MM and ER assisted in designing the study, and helped in the, interpretation of the study. All authors read and approved the final manuscript

Funding

Not declared. 


\section{Availability of data and materials}

Datasets are available through the corresponding author upon reasonable request.

\section{Ethics approval and consent to participate}

Not declared.

\section{Consent for publication}

Not applicable.

\section{Competing interests}

The authors declare that they have no competing interests.

Received: 15 June 2019 Accepted: 21 August 2019

Published online: 27 August 2019

\section{References}

1. Zamanzadeh V, Zirak M, Hemmati Maslakpak M, Parizad N. Distance education and diabetes empowerment: a single-blind randomized control trial. Diabetes Metab Syndr. 2017;11(Suppl 1):S247-51.

2. Prevalence of Diabetes in the World, 2013. https://www.who.int/newsroom/fact-sheets/detail/diabetes. Accessed 30 Oct 2018.

3. Alex. Statistics about Diabetes. American Diabetes Association. http:// www.diabetes.org/diabetes-basics/statistics/. Accessed 27 July 2016.

4. International Diabetes Federation Middle EST and North Africa. Iran vs world prevalence of diabetes http://www.idf.org/membership/mena/ iran. Accessed 27 July 2016.

5. Psarou A, Cooper H, Wilding JPH. Patients' perspectives of oral and injectable type 2 diabetes medicines, their body weight and medicine-taking behavior in the UK: a systematic review and meta-ethnography. Diabetes Ther. 2018;9(5):1791-810.

6. Rieusset J. Role of endoplasmic reticulum-mitochondria communication in type 2 diabetes. Adv Exp Med Biol. 2017:997:171-86.

7. Owiredu WK, Amidu N, Alidu H, Sarpong C, Gyasi-Sarpong CK. Determinants of sexual dysfunction among clinically diagnosed diabetic patients. Reprod Biol Endocrinol. 2011;9:70.

8. Vigersky R, Shrivastav M. Role of continuous glucose monitoring for type 2 in diabetes management and research. J Diabetes Compl. 2017;31(1):280-7.

9. Balon R, editor. Sexual dysfunction: the brain-body connection. Karger Medical and Scientific Publishers: Basel; 2008

10. Trief MP, et al. Marital quality and diabetes out com: the ideate project. Fam Syst Health. 2006;24:318.

11. Parker JN, Parker PM. Female sexual dysfunction: A medical dictionary, bibliography, and annotated research guide to internet references. 2004

12. World Health Organization (WHO). Sexual and Reproductive Health Defining Sexual Health. 2006. ehntt/p://www.who.int/reproductivehea Ith/topics/sexual_health/sh_definitions/en. Accessed 15 Jan 2016.

13. Berek JS. Berek and Novak's gynocology. 14th ed. Philadelphia: Lippincott Williams and Wilkins; 2012.

14. Ramezani Tehrani F, Farahmand M, Simbar M, Malek Afzali H. Factors associated with sexual dysfunction; a population based study in Iranian reproductive age woman. Arc Iran Med. 2014;17(10):679-84.

15. American Psychiatric Association. Diagnostic and statistical manual of mental health disorders. 5th ed. Arlington: American Psychiatric Association; 2013.

16. Muniyappa R, Norton M, Dunn ME, Banerji MA. Diabetes and female sexual dysfunction: moving beyond "benign neglect". Curr Diab Rep. 2005;5(3):230-6

17. Kadioglu P, Yalin AS, Tiryakioglu O, Gazioglu N, Oral G, Sanli O, Onem K, Kadioglu A. Sexual dysfunction in women with hyperprolactinemia: a pilot study report. J Urol. 2005;174(5):1921-5.

18. Guay AT. Sexual dysfunction in the diabetic patient. Int J Impot Res. 2001;13(S5):S47-50

19. Hintistan S, Cilingir D. Sexual dysfunction in Turkish men and women with type 2 diabetes mellitus. Sex Disabil. 2013;31(1):31-41.

20. Miocic J, Car N, Metelko Z. Sexual dysfunction in women with diabetes mellitus. Diabetologia Croatica. 2008;37(2):35-42.
21. Omidvar S, Niaki MT, Amiri FN, Kheyrkhah F. Sexual dysfunction among women with diabetes mellitus in a diabetic center in Amol. J Nat Sci Biol Med. 2013:4(2):321-4.

22. Appa AA, Creasman J, Brown JS, Van Den Eeden SK, Thom DH, Subak $L L$, Huang AJ. The impact of multimorbidity on sexual function in middle-aged and older women: beyond the single disease perspective. J Sex Med. 2014:11(11):2744-55

23. Oliveira-e-Silva T, Campos Pinheiro L, Rocha Mendes J, Barroso E, Monteiro Pereira N. Peripheral polyneuropathy and female sexual dysfunction-familial amyloidotic polyneuropathy as an example besides diabetes mellitus. J Sex Med. 2013;10(2):430-8.

24. Bhasin S, Enzlin P, Coviello A, Basson R. Sexual dysfunction in men and women with endocrine disorders. Lancet. 2007:369(9561):597-611.

25. Kettaş E, Çayan F, Akbay E, Kıykım A, Çayan S. Sexual dysfunction and associated risk factors in women with end-stage renal disease. J Sex Med. 2008:5(4):872-7.

26. Ismail AH, Baw R, Sidi H, Guan NC, Midin M, Nik Jaafar NR, et al. Orgasmic dysfunction among Malay diabetic women in Malaysia. Compr Psychiatry. 2014;55(Suppl 1):S29-33.

27. Taloyan M, Wajngot A, Johansson SE, Tovi J, Sundquist K. Sexual dysfunction in Assyrian/Syrian immigrants and Swedish-born persons with type 2 diabetes. BMC Res Notes. 2012;5(522):1-6.

28. Wallner LP, Sarma AV, Kim C. Sexual functioning among women with and without diabetes in the Boston Area Community Health Study. J Sex Med. 2010;7(2 Pt 2):881-7.

29. Alizadeh NS, Arasteh M, Mohsenpour B, Karimian F, Alizadeh NS. Comparison of sexual dysfunction between diabetic and non-diabetic women. J Midlife Health. 2013;4(3):167-71.

30. Duman NB. Frequency of sexual dysfunction and its causative factors among diabetic women in Turkey. Pak J Med Sci. 2014;30(3):558-63.

31. Pasquali D, Maiorino MI, Renzullo A, Bellastella G, Accardo G, Esposito D, Barbato F, Esposito K. Female sexual dysfunction in women with thyroid disorders. J Endocrinol Invest. 2013;36(9):729-33.

32. Enzlin P, Mathieu C, Demytteanere K. Diabetes and female sexual functioning: a state of-the-art. Diabetes Spectrum. 2003;16(4):256-9.

33. Copeland KL, Brown JS, Creasman JM, Van Den Eeden SK, Subak LL, Thom $\mathrm{DH}$, et al. Diabetes mellitus and sexual function in middle-aged and older women. Obstet Gynecol. 2012:120(2 Pt 1):331-40.

34. Dimitropoulos K, Bargiota A, Mouzas O, Melekos M, Tzortzis V, Koukoulis G. Sexual functioning and distress among premenopausal women with uncomplicated type 1 diabetes. J Sex Med. 2012;9(5):1374-81.

35. Ozcan S, Sahin NH, Bilgic D, Yilmaz SD. Is sexual dysfunction associated with diabetes control and related factors in women with diabetes? Sex Disabil. 2011;29(3):251-61.

36. Rutherford D, Collier A. Sexual dysfunction in women with diabetes mellitus. Gynecol Endocrinol. 2005;21(4):189-92.

37. Meeking DR, Fosbury JA, Cummings MH. Sexual dysfunction and sexual health concerns in women with diabetes. Pract Diabetes. 2013:30(8):327

38. Ismail AH, Bau R, Sidi H, Guan NC, Naing L, Jaafar NRN, et al. Factor analysis study on sexual responses in women with type 2 diabetes mellitus. Compr Psychiatry. 2014;55(S1):S34-7.

39. Ali RMA, Hajeri RMA, Khader YS, Shegem NS, Ajlouni KM. Sexual dysfunction in Jordanian diabetic women. Diabetes Care. 2008;31(8):1580-1.

40. Erol B, Tefekli A, Ozbey I, Salman F, Dincag N, Kadioglu A, Tellaloglu S. Sexual dysfunction in type II diabetic females: a comparative study. J Sex Marital Ther. 2002;28(Suppl 1):55-62.

41. Doruk H, Akbay E, Cayan S, Akbay E, Bozlu M, Acar D. Effect of diabetes mellitus on female sexual function and risk factors. Arch Androl. 2005;51(1):1-6.

42. Najafi M, Mirhoseini M, Moghani Lankarani M, Assari S. Correlation between sexual dysfunction and marital dissatisfaction among diabetics. Iran J Endocrinol Metab. 2006:8(2):175-9.

43. Mezones-Holguin E, Blümel JE, Huezo M, Vargas R, Castro J, Córdova W, Valenzuela G, Castelo-Branco C. Impact of diabetes mellitus on the sexuality of Peruvian postmenopausal. Gynecol Endocrinol. 2008;24(8):470-4.

44. Ogbera AO, Chinenye S, Akinlade A, Eregie A, Awobusuyi J. Frequency and correlates of sexual dysfunction in women with diabetes mellitus. J Sex Med. 2009:6(12):3401-6. 
45. Esposito K, Maiorino MI, Bellastella G, Giugliano F, Romano M, Giugliano D. Determinants of female sexual dysfunction in type 2 diabetes. Int J Impot Res. 2010;22(3):179-84.

46. Ziaei-Rad M, Vahdaninia M, Montazeri A. Sexual dysfunctions in patients with diabetes: a study from Iran. Reprod Biol Endocrinol. 2010;8:50.

47. Giugliano F, Maiorino MI, Di Palo C, et al. Adherence to mediterranean diet and sexual function in women with type 2 diabetes. J Sex Med. 2010;7(5):1883-90.

48. Nowosielski K, Skrzypulec-Plinta V. Mediators of sexual functions in women with diabetes. J Sex Med. 2011;8(9):2532-45.

49. Shi YF, Shao XY, Lou QQ, Chen YJ, Zhou HJ, Zou JY. Study on female sexual dysfunction in type 2 diabetic Chinese women. Biomed Environ Sci. 2012;25(5):557-61.

50. Sharifiaghdas F, Azadvari M, Shakhssalim N, Roohi-Gilani K, RezaeiHemami M. Female sexual dysfunction in type 2 diabetes: a case control study. Med Princ Pract. 2012;21(6):554-9.

51. Kaya Erten Z, Zincir H, Ozkan F, Selçuk A, Elmali F. Sexual lives of women with diabetes mellitus (type 2) and impact of culture on solution for problems related to sexual life. J Clin Nurs. 2014;23(7-8):995-1004.

52. Vafaeimanesh J, Raei M, Hosseinzadeh F, Parham M. Evaluation of sexual dysfunction in women with type 2 diabetes. Indian J Endocrinol Metab. 2014;18(2):175-9.

53. Cordero IA, Pulido JM, Rosa YA. Prevalencia de las alteraciones de la función sexual (AFS) en sujetos mexicanos con diabetes mellitusde tipo 1 (DM1) y 2 (DM2) que acuden a una Unidad Médica de Alta Especialidad (UMAE). Gaceta Médica de México. 2014;150(Suppl 1):107-13.

54. Shadman Z, Akhoundan M, Poorsoltan N, Larijani B, Arzaghi SM, Khoshniat M. Factors Associated with sexual function in iranian women with type 2 diabetes mellitus: partner relationship as the most important predictor. Iran Red Crescent Med J. 2014;16(3):e14941.

55. Bjerggaard M, Charles M, Kristensen E, Lauritzen T, Sandbæk A, Giraldi A. Prevalence of sexual concerns and sexual dysfunction among sexually active and inactive men and women with screen-detected type 2 diabetes. Sex Med. 2015;3(4):302-10.

56. Elyasi F, Kashi Z, Tasfieh B, Bahar A, Khademloo M. Sexual dysfunction in women with type 2 diabetes mellitus. Iran J Med Sci. 2015:40(3):206-13.

57. Mazzilli R, Imbrogno N, Elia J, Delfino M, Bitterman O, Napoli A, Mazzilli F. Sexual dysfunction in diabetic women: prevalence and differences in type 1 and type 2 diabetes mellitus. Diabetes Metab Syndr Obes. 2015:8:97-101.

58. Ammar M, Trabelsi L, Chaabene A, Charfi N, Abid M. Evaluation of sexual dysfunction in women with type 2 diabetes. Sexologies. 2017;26(3):17-20

59. Li F, Wang Y, Xiao L, Lou Q, Fish AF. Frequency, severity, and risk factors related to sexual dysfunction in Chinese women with T2D. J Diabetes. 2016:8(4):544-51.

60. Bąk E, Marcisz C, Krzemińska S, Dobrzyn-Matusiak D, Foltyn A, DrosdzolCop A. Relationships of sexual dysfunction with depression and acceptance of illness in women and men with type 2 diabetes mellitus. Int J Environ Res Public Health. 2017;14:9.

61. AlMogbel TA, Amin HS, AISaad SM, AlMigbal TH. Prevalence of sexual dysfunction in saudi women with Type 2 diabetes: is it affected by age, glycemic control or obesity? Pak J Med Sci. 2017;33(3):732-7.

62. Marques N, Cardoso J. Sexual dysfunction in portuguese women with type 2 diabetes. 40th easd annual meeting of the European Association for the Study of Diabetes: Munich, Germany, 5-9 September 2004. Diabetologia. 2004; 47(Suppl 1):A1-A464.

63. Ponholzer A, Roehlich M, Racz U, Temml C, Madersbacher S. Female sexual dysfunction in a healthy Austrian cohort: prevalence and risk factors. Eur Urol. 2005:47(3):366-74.
64. Hartmann U, Philippsohn S, Heiser K, Ruffer-Hesse C. Low sexual desire in midlife and older women: personality factors, psychosocial development present sexuality. Menopause. 2004;11(6 Pt 2):726-40.

65. Enzlin P, Mathieu C, Van den Bruel A, Bosteels J, Vanderschueren D, Demyttenaere K. Sexual dysfunction in women with type 1 diabetes. Diabetes Care. 2002;25:672-7.

66. Steinberg $\mathrm{HO}$, et al. Type II diabetes abrogates sex differences in the endothelial function in premenopausal women. Circulation. 2000;101:2040-6.

67. Balletshofer BM, et al. Endothelial dysfunction is detectable in young normotensive first-degree relatives of subjects with type 2 diabetes in association with insulin resistance. Circulation. 2000;101:1780-4.

68. Laumann EO, Nicolosi A, Glasser DB, et al. sexual problems among women and men aged 40-80y: prevalence and correlates identified in the Global study of sexual Attitudes and Behaviors. Int J Impot Res. 2005; 17:39-57.

69. Dennerstein L, Randolph J, Taffe J, Dudley E, Burger H. Hormones, mood, sexuality, and the menopausal transition. Fertil steril. 2002;77(suppl 4):42-8.

70. Pontiroli AE, Cortelazzi D, Morabito A. Female sexual dysfunction and diabetes: a systematic review and meta-analysis. J Sex Med. 2013;10:1044-51.

71. Tyrer G, Steel JM, Ewing DJ, Bancroft J, Warner P, Clarke BF. Sexual responsiveness in diabetic women. Diabetologia. 1983;24:166-71.

72. Meeking DR, et al. Sexual dysfunction and sexual health concerns in women with diabetes. Sex Dysfunc. 1998;1:83-7.

73. Schreiner-Engel $P$, Schiavi RC, Vietorisz D, Smith $H$. The differential impact of diabetes type on female sexuality. J Psychosom Res. 1987;31:23-33.

74. Enzlin P, Mathieu C, Demytteanere K. Diabetes and female sexual functioning: a state-of-the-art. Diabetes Spectrum. 2003;16:256-9.

75. Afshari $\mathrm{P}$, Yazdizadeh S, Abedi P, Rashidi $\mathrm{H}$. The relation of diabetes type 2 with sexual function among reproductive age women in Iran, a casecontrol study. Adv Med. 2017;2017:4838923.

76. Veronelli A, Mauri C, Zecchini B, Peca MG, Turri O, Valitutti MT, Dall'Asta C, Pontiroli AE. Sexual dysfunction is frequent in premenopausal women with diabetes, obesity, and hypothyroidism, and correlates with markers of increased cardiovascular risk. A preliminary report. J Sex Med. 2009;6(6):1561-8

77. Naghavi M, Fatemi S, Abutorabi R. Evaluation of sexual function in women with type 2 diabetes. J Diabetes Metab Iran. 2009;8(4):357-62.

78. Olarinoye J, Olarinoye A. Determinants of sexual function among women with type 2 diabetes in a Nigerian population. J Sex Med. 2008;5:878-86.

79. Nappi R, Salonia A, Traish AM, van Lunsen RH, Vardi Y, Kodiglu A, et al. Clinical biologic pathophysiologies of women's sexual dysfunction. J Sex Med. 2005;2(1):4-25.

80. Maseroli E, Fanni E, Cipriani S, Scavello I, Pampaloni F, Battaglia C. Cardiometabolic risk and female sexuality: focus on clitoral vascular resistance. Sex Med. 2016;13(11):1651-61.

\section{Publisher's Note}

Springer Nature remains neutral with regard to jurisdictional claims in published maps and institutional affiliations.

Ready to submit your research? Choose BMC and benefit from:

- fast, convenient online submission

- thorough peer review by experienced researchers in your field

- rapid publication on acceptance

- support for research data, including large and complex data types

- gold Open Access which fosters wider collaboration and increased citations

- maximum visibility for your research: over 100M website views per year

At $\mathrm{BMC}$, research is always in progress.

Learn more biomedcentral.com/submissions 